\title{
Landslide susceptibility in the Belt and Road Countries: continental step of a multi-scale approach
}

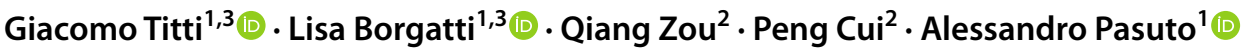

Received: 6 October 2020 / Accepted: 15 August 2021 / Published online: 14 September 2021

(c) The Author(s) 2021

\begin{abstract}
The Belt and Road Initiative is a collaboration project launched by the Chinese Government to connect more than 65 countries all over the word by developing infrastructures, facilities, and support collaborations among involved Countries. The Silk Road Disaster Risk Reduction is a sub-project of the Belt and Road Initiative focused on mitigation and prevention of natural risks in the involved countries. In this context, this work presents a method to approach landslide susceptibility zoning on a continental scale that takes into account the limitations due to the completeness of landslide inventories and the scale and data quality of causal factors. A first attempt to produce a pixel-based statistical susceptibility map is described. All the data and software used in this work are open and open source. The landslide susceptibility zoning has been carried out in south-Asia using the NASA-COOLR landslide dataset through the Weight of Evidence method and it has been evaluated and validated by means of the ROC analysis. The results reveal a good prediction capacity and highlights that slope, relative relief and annual precipitation are the causative factors that play a major role in predisposing slope instability in the study area. Based on them, the method will be applied to the rest of the Belt and Road Countries.
\end{abstract}

Keywords Landslide susceptibility $\cdot$ Continental scale $\cdot$ Belt and Road Initiative $\cdot$ Weight of evidence

\section{Introduction}

The Belt and Road Initiative (BRI) is a collaboration project launched by the Chinese Government to connect more than 65 countries all over the word by developing infrastructures, facilities and support among the involved Countries and to

This article is part of a Topical Collection in Environmental Earth Sciences on "GeosphereAnthroposphere Interlinked Dynamics: Geocomputing and New Technologies", guest edited by Sebastiano Trevisani, Marco Cavalli, and Fabio Tosti.

Giacomo Titti

giacomo.titti2@unibo.it

1 Research Institute for Geo-Hydrological Protection, Italian National Research Council, C.So Stati Uniti, 4, 35127 Padova, Italy

2 Institute of Mountain Hazards and Environment, Chinese Academy of Science, South Renmin Road, Section 4, 9, Chengdu 610041, China

3 Department of Civil, Chemical, Environmental and Materials Engineering, ALMA MATER STUDIORUM University of Bologna, Viale Risorgimento, 2, 40136 Bologna, Italy encourage innovation in less developed Countries (Cui et al. 2017; Liu and Dunford, 2016).

The Silk Road Disaster Risk Reduction (SiDRR) project (Lei et al. 2018) is one of the prioritized sub-projects of the BRI . The purpose of the SiDRR is to carry out a long-term research project dealing with natural hazard assessment and risk mitigation in the Belt and Road Countries. A group of experts, with the role of scientific coordination of the activities carried out by the involved Countries, as well as the dissemination of the results, has been created. The expected outcomes of the research activities of the group are the assessment of geo-hydrological hazards in the Belt and Road Countries and the definition of risk mitigation measures.

Risk, hazard and susceptibility zoning are three complementary approaches to support land planning. They implicate a decreasing complexity in method and in data types, respectively. Considering the small scale of the SiDRR analysis and the available data, a landslide susceptibility zoning has been proposed to build a map which should give a general overview of the landslide-prone areas in the Belt and Road Countries. The goal is to individuate the most susceptible areas where to focus further and more detailed assessments. "In mathematical form, landslide susceptibility, is the 
probability of spatial occurrence of known slope failures, given a set of geoenvironmental conditions" (Guzzetti et al. 2006). Otherwise, landslide susceptibility can be defined as the spatial component of the hazard (Reichenbach et al. 2018) which, in turn, is the combination of the frequency of landslide occurrence and the susceptibility map (Fell et al. 2008). Thus, landslide susceptibility can be considered a fundamental part of the process to reach landslide hazard and risk assessment. At the same time, it can be used in land use planning for large areas or in analyses characterized by scarcity of data (Corominas et al. 2014).

This work will support the development of landslide hazard prevention and mitigation measures proposing a multiscale approach for landslide susceptibility zoning and discussing its first application in a test area.

The used scale classification has been derived by Glade and Crozier (2012) and introduced by Soeters and Van Westen (1996). One class has been added to the original ranges: large scales $(>1: 10,000)$, medium scales $(1: 15,000-1: 100,000)$, regional scales $(1: 125,000-1: 500,000)$, national scales $(1: 750,000-1: 2,000,000)$ and continental scales $(<1: 5,000,000)$.

An approach to landslide susceptibility assessment based on the analysis of the state-of-the-art is presented, where the terms "large area" and "small scale" are used as synonyms and they refer to continental scale. To show the feasibility and the robustness of the suggested approach, the case study of south-Asia has been analyzed. The results have been evaluated and validated by means of ROC analysis.

\section{State of the art}

Landsliding is a complex process driven by several possible predisposing and triggering factors. Numerous causative factors (geo-environmental factors) may predispose slope to failure, such as: geology, topography, tectonics, land cover and use, hydrology, and others (Eckelmann et al. 2006). On the other hand, the processes which trigger a landslide can be different and include: intense or prolonged rainfall, earthquakes, rapid snow melting, volcanic activity, human actions and others (Guzzetti et al. 2012).

The goal of landslide susceptibility zoning is to analyze the probability of landslide occurrence under the influence of a combination of factors, not including landslide frequency. Therefore, the temporal factor is not taken into consideration (Chacón et al. 2006).

Many different methods have been proposed for landslide susceptibility zoning in the scientific literature. The choice of a susceptibility mapping method significantly influences the prediction capacity of the analysis. According to Corominas et al. (2014), the methods can be categorized as qualitative (knowledge-driven methods) and quantitative (data-driven methods). The former take advantage of the theoretical and empirical knowledge of the researchers to make scientific analysis and judgment (Axing et al. 2010; Ayalew et al. 2004; Barredo et al. 2000; Günther et al. 2014; Saaty 1990). The latter recreates the relation between landslides and their controlling factors using a mathematical model: physically (Chung and Fabbri 2003; Goetz et al. 2011; Gorsevski et al. 2006) or statistics-based (Agterberg et al. 1989; Bonham-Carter et al. 1988; Bui et al. 2016; Carrara et al. 2008; Catani et al. 2013; Chen et al. 2016, 2017; Constantin et al. 2011; Eeckhaut et al. 2012; Gorsevski et al. 2000; Pham et al. 2016; Yao et al. 2008).

Reichenbach et al. (2018) pointed out that Logistic Regression is one of the most diffuse statistics-based models for landslide susceptibility on both large and small scales. Concerning landslide susceptibility assessment at continental, or similar scale, several different methodologies have been used so far. Most of them are knowledge-driven methods and statistic-based methods. In addition, physically based methods are excluded in small scale analyses, because they require a detailed knowledge of the landslide dynamics, which is not feasible for large areas.

The scarcity of data, which is very common in smallscale analyses, may be a driven factor in model selection. In particular, the lack of landslide inventories may affect the robustness and quality of the results. However, as stated by Hong et al. (2007) this is not always true: "more information does not necessarily lead to better results, depending on the quality of the data".

Due to the lack of a global landslide data set at that time, Hong et al. (2007) have produced a global landslide susceptibility map without landslide inventories. They have weighted the causative factors on the base of reference studies and information available combined through a linear combination method. Following a similar idea, Eeckhaut et al. (2012) proposed a statistical model application with limited landslide inventory data. They evaluated the landslide susceptibility over Europe with the Logistic Regression model.

The recent development of global landslide inventories has supported new analyses at global scale (e.g., Kirschbaum and Stanley 2018; Stanley and Kirschbaum, 2017) which have produced a global landslide susceptibility map for rainfall-triggered landslides based on the fuzzy overlay method. This approach combines landslide inventories with expert opinions to develop a heuristic model.

At the continental scale, Günther et al. (2014) and then Wilde et al. (2018) presented the landslide susceptibility maps of Europe, named ELSUSv1 and ELSUSv2, respectively. Despite that, they had numerous national landslide inventories heterogeneously distributed, they have proposed a qualitative model (Spatial Multi Criteria Evaluation) using Analytical Hierarchy Process. 
Fig. 1 Study area of the southAsia

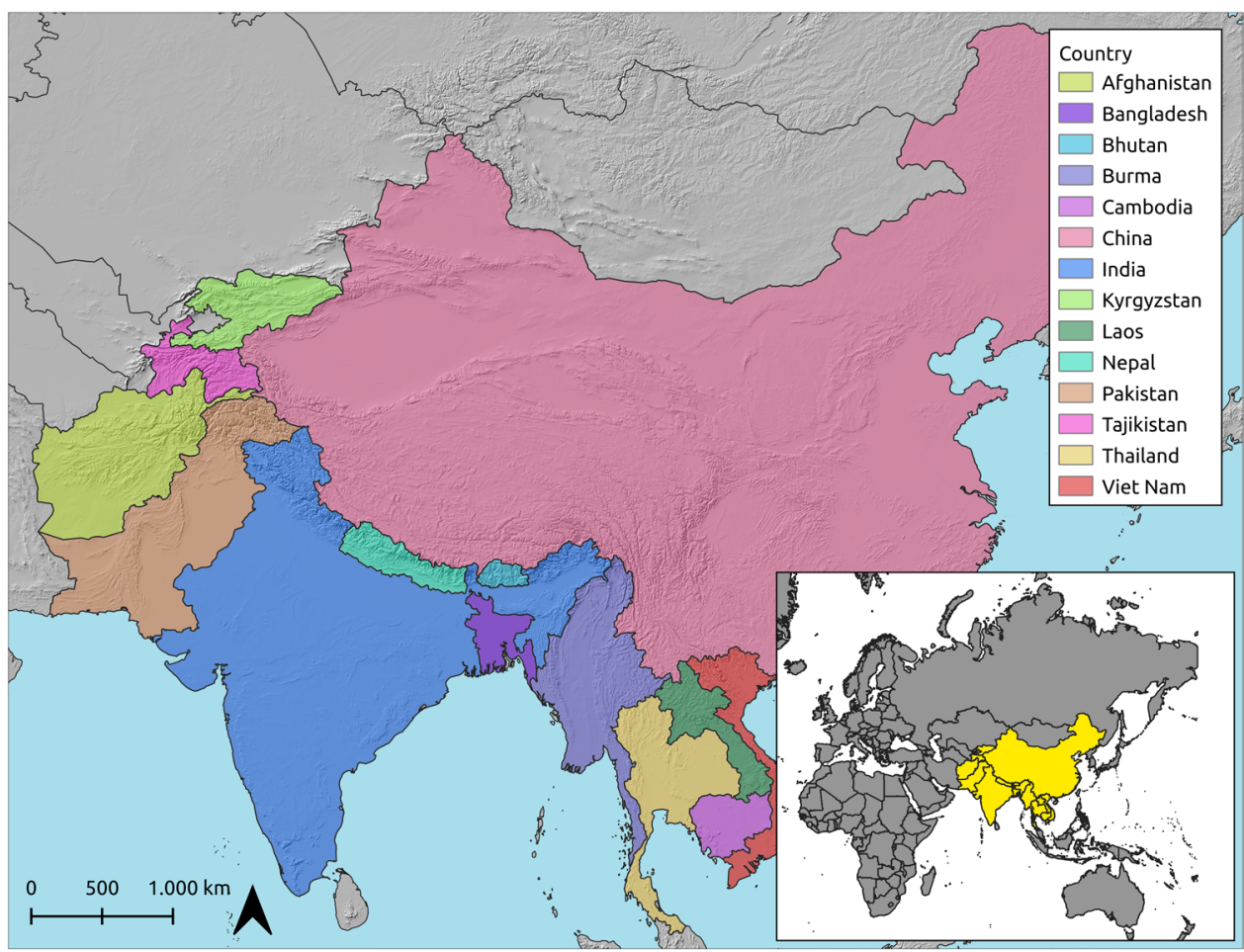

A different approach at continental scale has been used by (Broeckx et al. 2018) who analyzed the landslide susceptibility all over Africa based on a well-distributed inventory applying Logistic Regression model.

As a concern, the study area here considered (SouthAsia) numerous landslide susceptibility maps at national or smaller scale have been produced in recent years. Some of those, based on the Neural Network method with about 1300 landslides all over China are reported in Liu et al. (2013). Recently, Saponaro et al. (2015) have covered Uzbekistan, Tajikistan and Kyrgistan, using the Weight of Evidence method.

In the context of the European Union's Thematic Strategy for Soil Protection (EC, 2006), the Soil Information Working Group (SIWG) of the European Soil Bureau Network (ESBN) has promoted a project for the identification of landslide hazard priority areas. The European Landslide Expert Group (Günther et al. 2013a) has then put forward a multi-Tier susceptibility analysis in the Guidelines for Mapping Areas at Risk of Landslides in Europe (Hervás 2007). Taking inspiration from the latter, and considering, the extension of the study area and the geomorphological, geological, cultural, scientific heterogeneity of the context, the Weight of Evidence (WoE) method has been selected. Therefore, the application of the selected method and the Tier 1 approach at the southAsia region is presented here.

\section{Case study}

The Belt and Road Initiative involves 3 continents (63\% of the world), and more than 65 countries (Cui et al. 2017). The study area selected includes a relevant part of the Belt and Road Countries (Fig. 1), namely: China, Pakistan, India, Tajikistan, Bangladesh, Nepal, Afghanistan, Bhutan, Myanmar, Cambodia, Kyrgyzstan, Laos, Thailand, Viet Nam. The study area comprises a high density of landslides mainly triggered by heavy rainfall (more than $1600 \mathrm{~mm} / \mathrm{y}$ ) (Fig. 7) as well as some of the most disastrous earthquakes that have recently occurred in the world (i.e., Nepal 2015 and Wenchuan 2008). The diversity of climate, topography, geological features and land cover result in an extremely complex environment on which to assess landslide susceptibility.

\section{Materials and methods}

The Tiers-based workflow produced consequential susceptibility zoning of the same study area by growing scales (Fig. 2). The smallest scale provides an overview of the object of study and it delineates the priorities, i.e., the most susceptible regions. Therefore, Tier 1 assessment 


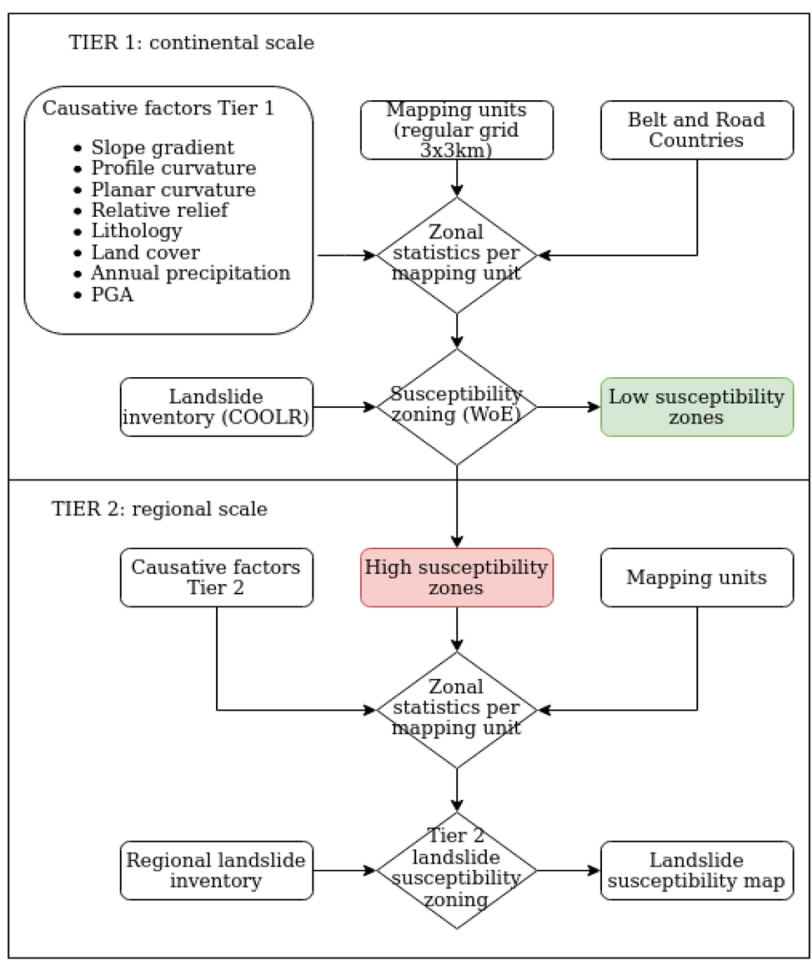

Fig. 2 Workflow of the Tiers-based approach

exploits low-resolution data and incomplete spatial information. With the increase of the scale of analysis, the Tier 2 approach is intended to detail the landslide susceptibility analysis conducted by the Tier 1 (Günther et al. 2013b). The scale of Tiers cannot be defined a priori, since it depends on the available data resolution and the spatial extent of the study area. This means that the results should reflect, at least, the minimum resolution of the data input.

The landslide prediction model represents the core of the entire analysis. The model proposed here is: (i) temporally/ geographically reproducible; (ii) simple and thus clear to the people involved; (iii) as realistic as possible. A qualitative assessment for Tier 1 level has been proposed by Günther et al. (2007). It was based on the expertise of the researchers responsible for the analysis, thus the reproducibility depends on the investigator. To make the results reproducible in time and in all areas, the assessment technique should be quantitative and as objective as possible. The use of physical predictors and of the validation procedure define the physical relevance of the model in accordance with the geological and geomorphological features of the study area. Therefore, to create a reproducible, simple, realistic landslide susceptibility map not affected by subjectivity, misunderstanding and abstraction, a limited number of causative factors related to all types of landslides and a quantitative susceptibility modeling technique, suitable to the specific Tier, have been assumed.
The landslide susceptibility concept is based on the simple principle that landsliding will occur more frequently in the most susceptible areas characterized by similar geo-environmental factors which predispose towards slope failures. A landslide inventory and selected causative factors are the preliminary requirements for susceptibility analysis (Van Westen et al. 2008), especially if a statistic-based correlation analysis is applied (Bui et al. 2016) in accordance with the scale of mapping, the required usage, and the quality of the data available (Fell et al. 2008).

A landslide inventory is an essential part of the input dataset in landslide susceptibility mapping. It generally records the location, the date of occurrence and type of mass movements (Margottini et al. 2013). In this analysis, three different alternatives have been taken into consideration: (i) aggregation and homogenization of all local landslide datasets available in the Countries involved in the project; (ii) development of a new landslide dataset; and (iii) collection of global landslide datasets. The latter solution has been selected due to the complexity of the aggregation processes and the lack of information. Indeed, the regional slope failure database is sometimes not complete or, more often, it is absent completely. The few data available locally are often limited to recent years and, therefore, not representative of the instability condition as it is.

The NASA-COOLR dataset (Juang et al. 2019) has been selected for the purpose of this work. It is an open database for landslide events launched in 2018 which collects different inventories from different sources: Landslide Reporter Catalog (LRC) (Juang et al. 2019), NASA Global Landslide Catalog (GLC) (Kirschbaum et al. 2010, 2015) and collated inventories from external local sources. The LRC includes landslide reports by citizen scientists through the Landslide Reporter and checked by NASA. The GLC is a global inventory of rainfall-triggered landslides compiled by NASA since 2007 and is based on online media reports, disaster databases, scientific reports and more (Kirschbaum et al. 2015). The rest of the landslides are added into the COOLR by the LRC and other sources such as the SERVIRMekong team for Myanmar landslides (SMMML). The team collected landslides based on Google Earth imagery (Juang et al. 2019).

The landslide inventory of COOLR used for the analysis was downloaded in June 2020. Each point in the inventory has been assigned a radius of confidence between 1 and $75 \mathrm{~km}$. In accordance with the spatial resolution of the analysis the landslide locations with $1 \mathrm{~km}$ of accuracy have been selected (1549 landslides). The landslide attributes are shown in Fig. 3 and Table 1. The heterogeneity of data sources implicates the variability of information. As a consequence, some information such as the exact location of the landslides have been collected but others remain unknown (e.g., landslide category and trigger). 

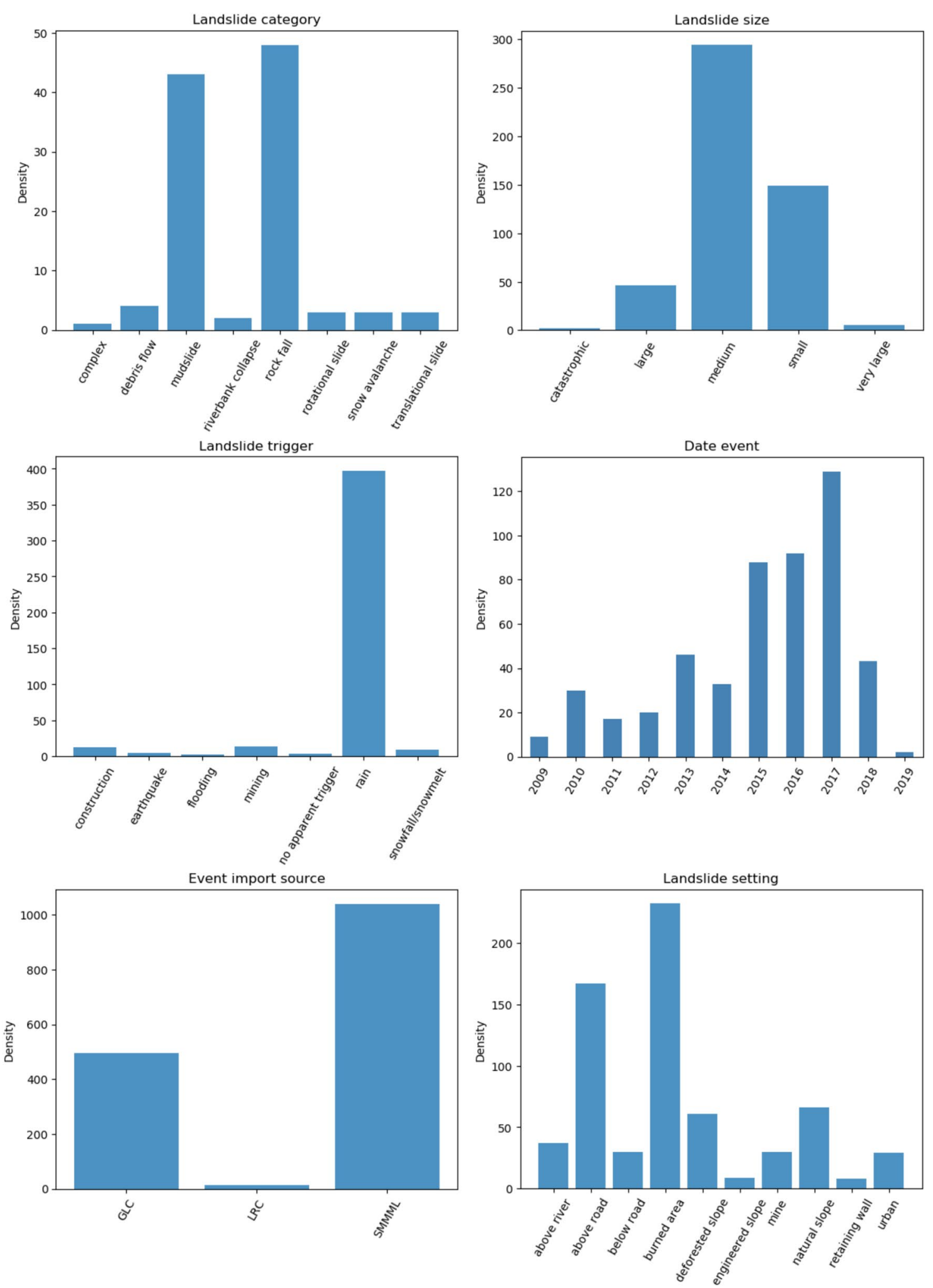

Fig. 3 Landslide frequencies classified by attributes of $1 \mathrm{~km}$ location accuracy dataset (1549). The attributes include 'unknown', 'others' and empty records which are not reported into the graphs. They are

1142 of 'landslide category', 1053 of 'landslide size', 1109 of 'landslide trigger', 1040 of 'date of the event' and 880 of 'landslide setting' 
Table 1 Number of COOLR landslides per country with location accuracy 'exact' or equal to $1 \mathrm{~km}$

\begin{tabular}{lr}
\hline Country & $\begin{array}{l}\text { Number of } \\
\text { COOLR land- } \\
\text { slides }\end{array}$ \\
\hline China & 44 \\
Afghanistan & 1 \\
Burma & 1038 \\
Cambodia & 1 \\
Bangladesh & 14 \\
Viet Nam & 2 \\
Thailand & 4 \\
Tajikistan & 7 \\
Nepal & 51 \\
Pakistan & 27 \\
Kyrgyzstan & 6 \\
Laos & 2 \\
Bhutan & 1 \\
India & 351 \\
\hline
\end{tabular}

Considering the limited information available on each event, a cross-check has been conducted to evaluate the reliability of the inventory for the purposes of this analysis. DEM and satellite images, along with a number of pictures, available for 118 landslides have been analyzed. The $250 \mathrm{~m}$ DEM has been downloaded from CIAT website (Reuter et al. 2007) which is the result of a resampling process from the $30 \mathrm{~m} \mathrm{SRTM} \mathrm{data.}$

The sample is not properly representative of the inventory, but, it allows some possible incompatibilities with the goal of the analysis to be highlighted. As a result, some features have been removed from the inventory. For example: 3 events are classified as snow avalanches, whereas 47 landslides appear to be related with human alterations of the natural landscape (mining, engineered slopes and retaining walls) which are strictly site-specific. In particular, for 6 of the latter a photo link is available. They show that slope instability events occurred during mining activities and construction works which are different from slope cutting, these are probably triggered by anthropic activities. It could be argued that all the 47 landslides have been probably triggered by antrophic activities as well and caused by the same conditions. Therefore, they have been deleted from the inventory. Then, given a radius of confidence of approximately $1 \mathrm{~km}$ around each feature $(9 \times 9$ cells of $250 \mathrm{~m}$-side pixel $)$, some features have been removed, since the slope of the terrain is lower than $3^{\circ}$, thus, they may be considered excavation collapses (38 events). At the end of this cross-check activity, 1461 landslides have been selected for the susceptibility zoning (Fig. 4).

The analysis focuses on the development of future scenarios based on the prediction of landslides spatial distribution.
It reproduces spatially the combination of factors responsible for previous events.

The selection of the causative factors for the multi-scale analysis depends on the Tier. In the context of the Tier 1 analysis, the considered causative factors are: slope degree, plan curvature, profile curvature, relative relief, lithology, land cover, Peak Ground Acceleration (PGA) and annual rainfall (Table 2).

As stated by (Fell et al. 2008), "areas with similar topography, geology and geomorphology as the areas which have experienced landsliding in the past are also likely to experience landsliding in the future". To identify the causes of past landslides and predict future scenarios, the statistical approach proposed in this work requires the classification of the causative factors. The classification significantly affects the prediction skill of the analysis. Therefore, classifications previously proposed in papers and technical reports have been assigned to the causative factors considered here. The diagram in Fig. 5 shows how the causative factors have been pre-processed.

The morphological factors for Tier 1 assessment have been classified according to the slope angle, plan curvature (curvature tangent to the contour line), profile curvature (curvature tangent to the slope line) and relative relief (the maximum range of elevation in a neighborhood of $1 \mathrm{~km}$ of radius).

The morphological factors have been derived from the 30 m Shuttle Radar Topography Mission (SRTM) DEM (Farr et al. 2007; Florinsky et al. 2019). The morphological factors have been calculated in Google Earth Engine (GEE) (Gorelick et al. 2017) using Terrain Analysis in Google Earth Engine (TAGEE) a GEE package for terrain analysis (Safanelli et al. 2020). GEE allowed us to calculate slope angle, plan and profile curvature and relative relief with a pixel size of $30 \mathrm{~m}$ then resampled into a square grid of $3 \times 3 \mathrm{~km}$ by average calculation. To reduce the computational cost and balance the amount of stable and unstable cells of the dataset, the $30 \mathrm{~m}$ cells with slope degree lower than $8^{\circ}$ have been masked for all the causative factors. This value has been selected considering the average slope of the debris flow fans which represent the steepest terrain in which landslides are not expected but accumulation landforms. Therefore, the valley bottoms along with all the depositional forms that couldn't be affected by instability processes in the mountain areas have been excluded from the analysis. The relief has been calculated as the range between the maximum and the minimum elevation in a buffer radius of $1 \mathrm{~km}$ around each $30 \mathrm{~m}$ pixel.

The slope angle (terrain gradient) classification reflects the classes used for the ELSUSv1 (Günther et al. 2014): $0^{\circ}, 1-3^{\circ}, 4-6^{\circ}, 7-10^{\circ}, 11-15^{\circ}, 16-20^{\circ}, 21-30^{\circ},>30^{\circ}$. The curvatures have been classified in quartiles. Therefore, profile curvature has been classified in: $<-2.610^{-4},-2.610^{-4}$ 


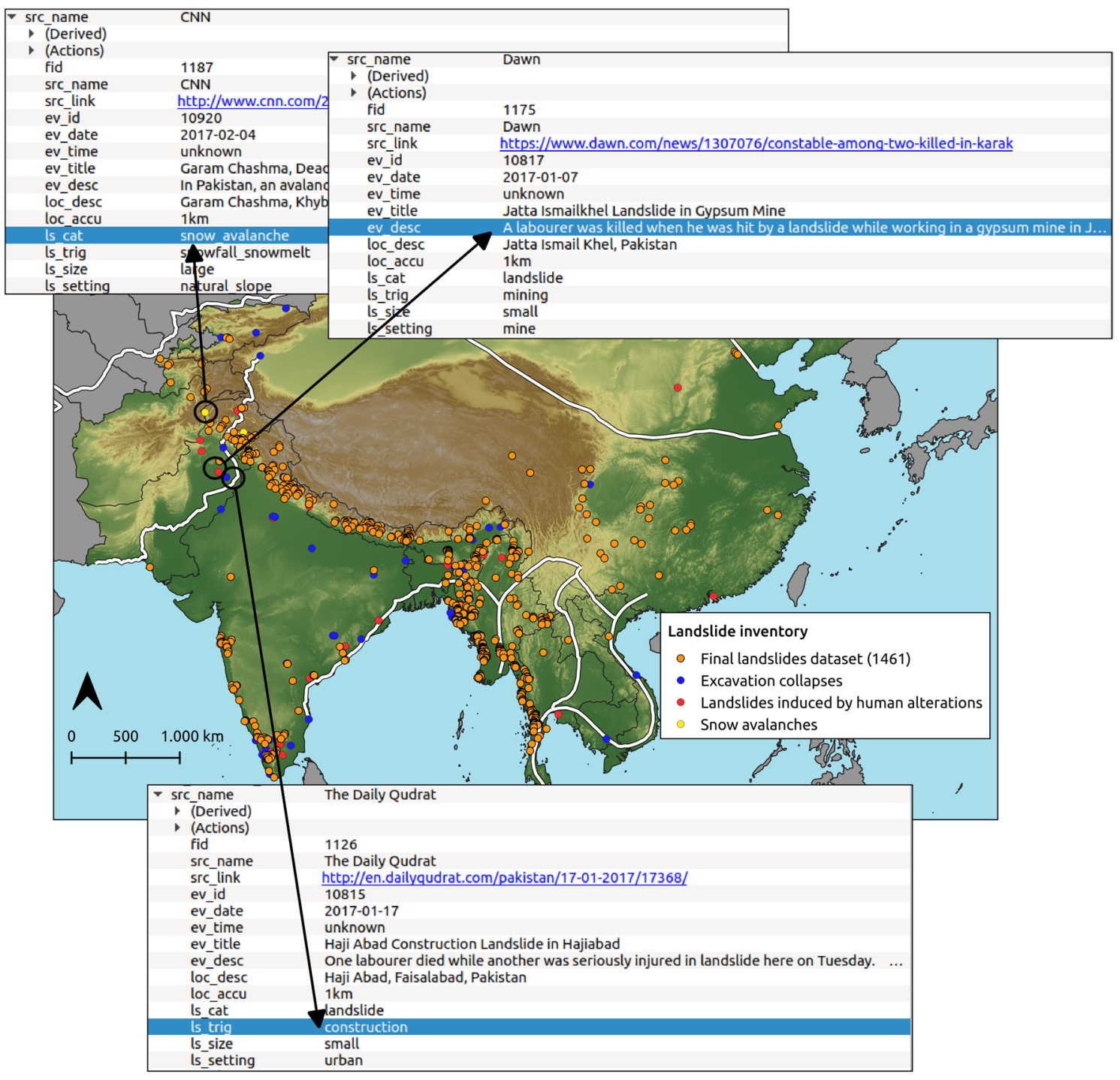

Fig. 4 Landslide dataset used for the analysis and the features removed after the cross-check

Table 2 Causative factors

\begin{tabular}{ll}
\hline Class factor & Factor \\
\hline Tier 1 & \\
Morphological & Slope angle \\
& Plan curvature \\
& Profile curvature \\
& Relative relief \\
Geological & Lithology \\
Environmental & Land cover \\
& PGA \\
& Annual rainfall \\
\hline
\end{tabular}

to $-1.410^{-4},-1.410^{-4}$ to $-5.410^{-5},-5.410^{-5}$ to 4.2

$10^{-5},>4.210^{-5}$. Plan curvature has been classified in: $<1.3$

$10^{-7}, 1.310^{-7}-1.210^{-4}, 1.210^{-4}-2.210^{-4}, 2.210^{-4}-3.8$
$10^{-4},>3.810^{-4}$. Relative relief has been divided in deciles: 0-9 m, 9-18 m, 18-34 m, 34-65 m, 65-120 m, 120-194 m, 194-288 m, 288-424 m, 424-625 m, > 625 m (Fig. 6).

The geological factor has been proposed by Hartmann and Moosdorf (2012). They have mapped the lithology of the globe into 16 classes, all of them present in South-Asia. They have been grouped into 7 classes: (1) ice, glaciers and water bodies; (2) siliciclastic sedimentary rocks, mixed sedimentary rocks, carbonate sedimentary rocks and pyroclastics; (3) mixed sedimentary rocks; (4) evaporites; (5) acid volcanic rocks, intermediate volcanic rocks, basic volcanic rocks; (6) acid plutonic rocks, intermediate plutonic rocks, basic plutonic rocks; and (7) metamorphic rocks (Fig. 7e).

In regards to the land cover classification, the ESA GlobCover 2009 Project has classified the land cover information into 22 classes (Bontemps et al. 2011) which have been 


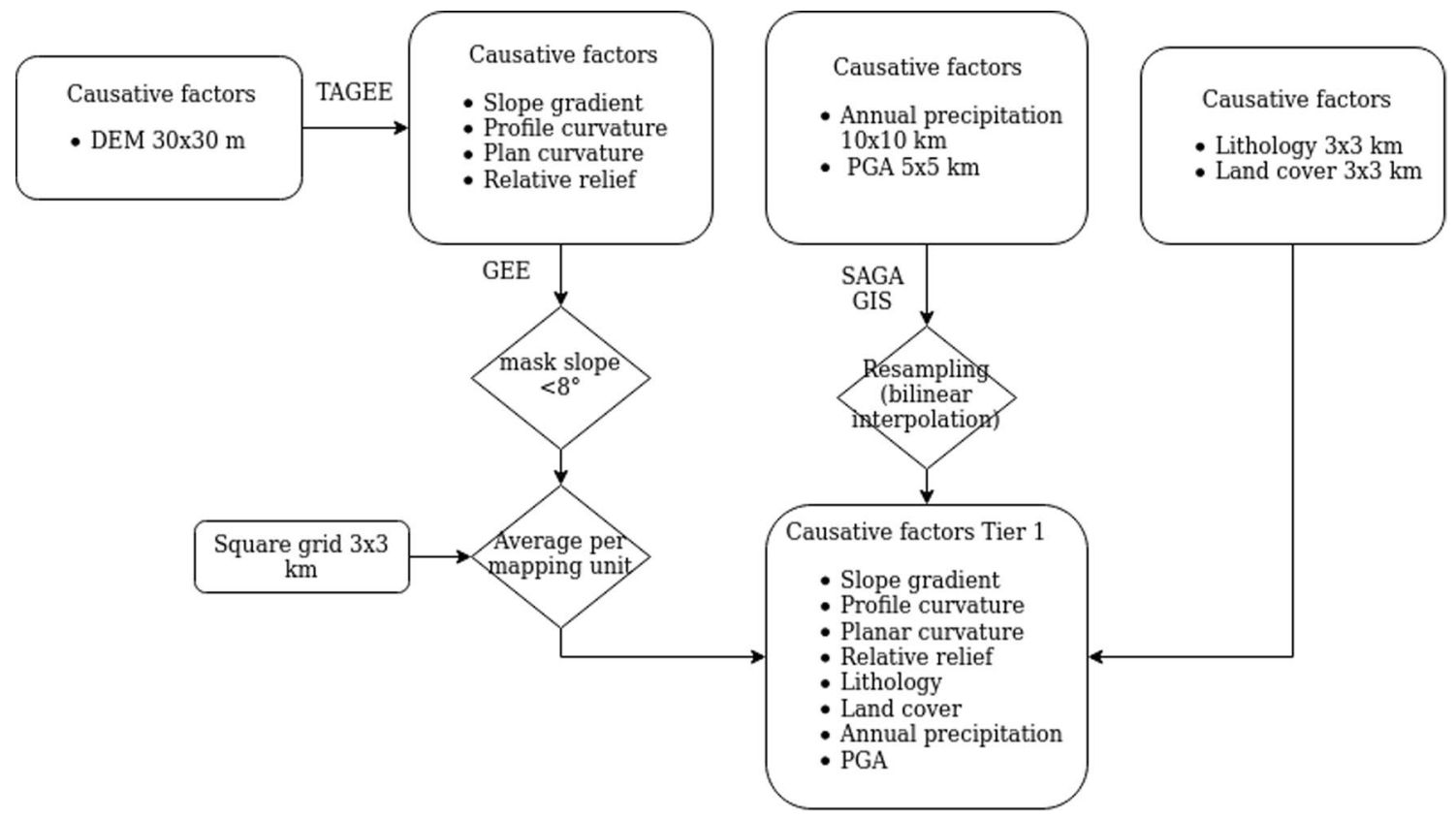

Fig. 5 Pre-processing of the causative factors

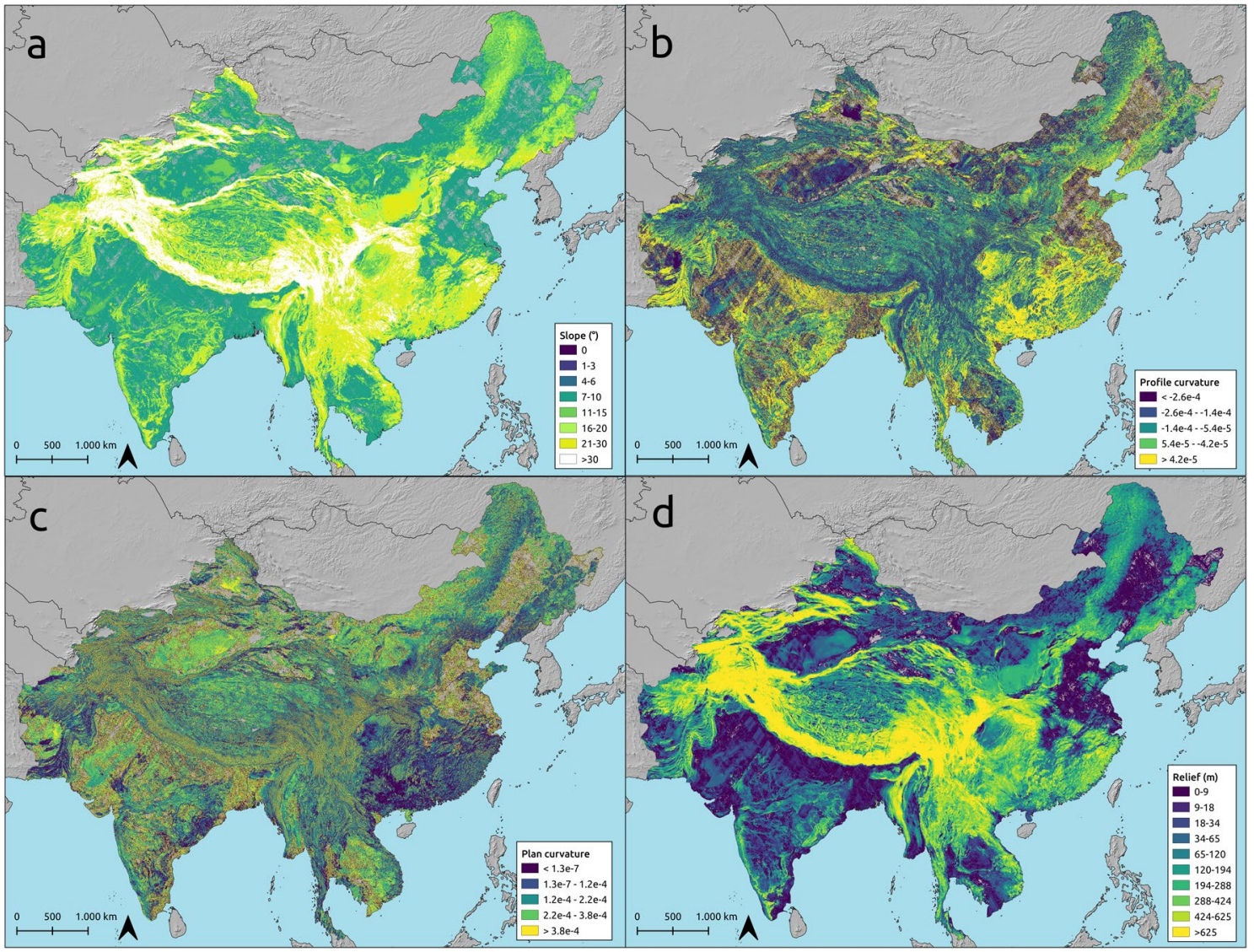

Fig. 6 Causative factors selected for the Tier 1 landslide susceptibility: a slope, $\mathbf{b}$ profile curvature $\mathbf{c}$ plan curvature and $\mathbf{d}$ relief 


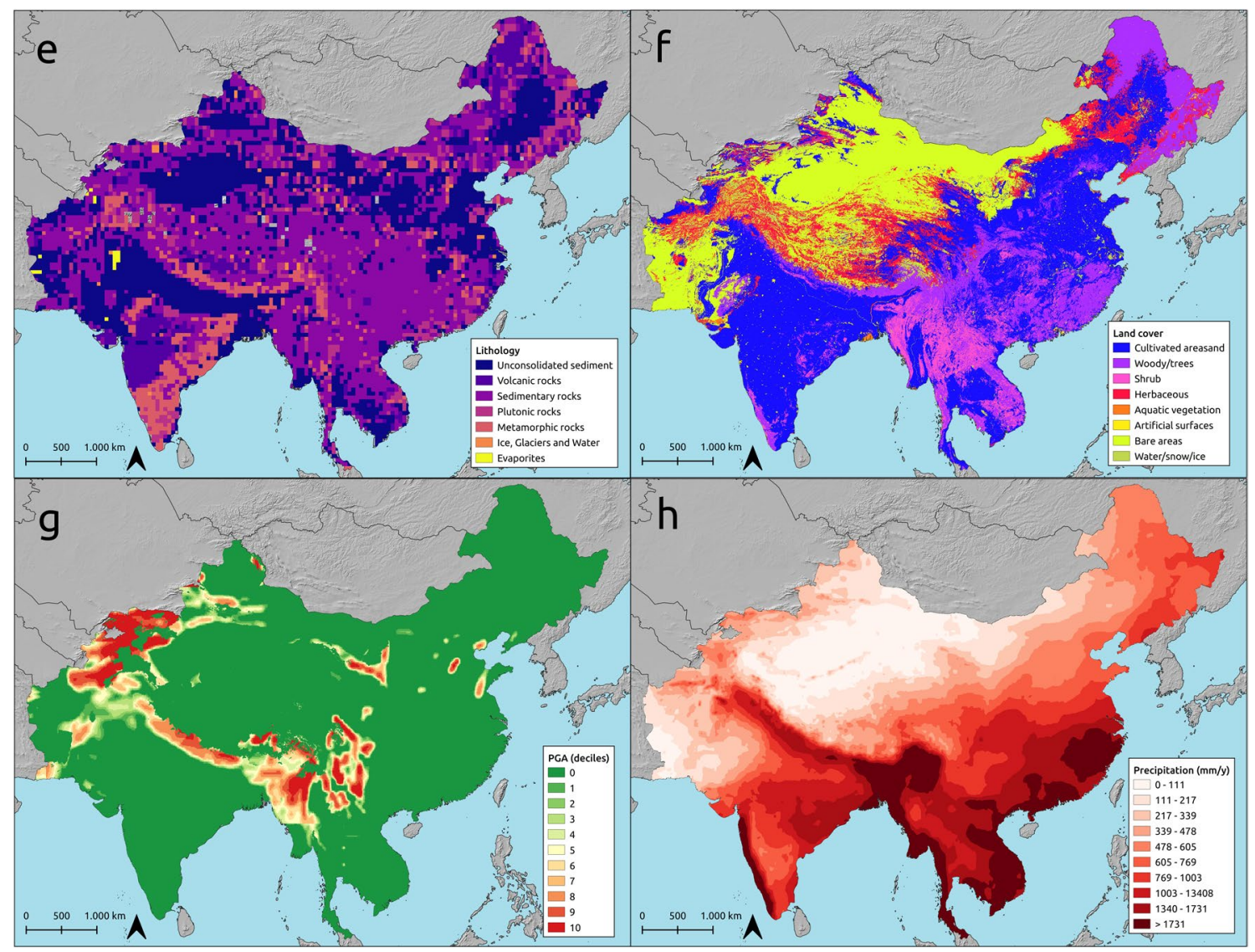

Fig. 7 Causative factors selected for the Tier 1 landslide susceptibility: $\mathbf{e}$ lithology, $\mathbf{f}$ land cover, $\mathbf{g}$ PGA and $\mathbf{h}$. precipitation

grouped into 8 categories (Table 3) according to the United Nations (FAO) Land Cover Classification System (LCCS) (Di Gregorio 2016). Therefore, the 8 LCCS classes have been suggested for Tier 1 land cover factor subdivision (Table 3) (Fig. 7f).

Since most of the landslides in Asia are mainly triggered by rainfall and earthquakes, two factors have been included: annual rainfall and PGA.

The annual rainfall factor has been calculated from the annual sum of the daily precipitation measured by the Multi-satellitE Retrievals for Global Precipitation Measure (IMERG) (Huffman et al. 2019) with a cell size of $10 \times 10 \mathrm{~km}$. The final result is the average of the annual precipitation over 11 years (2009-2019) resampled to a $3 \mathrm{~km}$ square grid using the bilinear resampling method of SAGA GIS. The map has been classified into deciles: $0-111 \mathrm{~mm} / \mathrm{y}$, 111-217 mm/y, 217-339 mm/y, 339-478 mm/y, 478-605 mm/y, 605-769 mm/y, 769-1003 mm/y, $1003-1340 \mathrm{~mm} / \mathrm{y}, 1340-1731 \mathrm{~mm} / \mathrm{y},>1731 \mathrm{~mm} / \mathrm{y}$ (Fig. 7 h).

The PGA map has been developed from a collaboration among the Columbia University Center for Hazards and Risk Research (CHRR) and Columbia University Center for International Earth Science Information Network (CIESIN) using Global Seismic Hazard Program (GSHAP) data. It includes areas with a probability to exceed at least $10 \%$ the PGA in a time span of 50 years $\left(>2 \mathrm{~m} / \mathrm{s}^{2}\right)$. The PGA have been classified into deciles from the 1th to the 10th (CHRR-Columbia University, CIESIN-Columbia University 2005, Dilley et al. 2005). The zero class has been added (Fig. 7g).

The details about the data type, source and quality are reported in Table 4. All the data used for the analysis are freely available from different global databases (Table 4) (Figs. 6, 7).

The WoE technique has been proposed for the mathematical evaluation of the Landslide Susceptibility Index (LSI). The WoE model introduced by Agterberg et al. (1989) and then by Bonham-Carter et al. (1988) is a bivariate statistical analysis, which compares dependent (landslide inventory) and independent variables (causative factors), it is used to evaluate landslide susceptibility (Pasuto and Tagliavini 2007). It assigns two weights $\left(W^{+}, W^{-}\right)$to the classes of each causative factor. The weights $W^{+}$and $W^{-}$mean that the presence of the factor is favorable to slope instability and the presence of the factor is favorable 
Table 3 Land cover classification conversion from GlobCover classification to LCCS (Bontemps et al. 2011; Di Gregorio 2016)

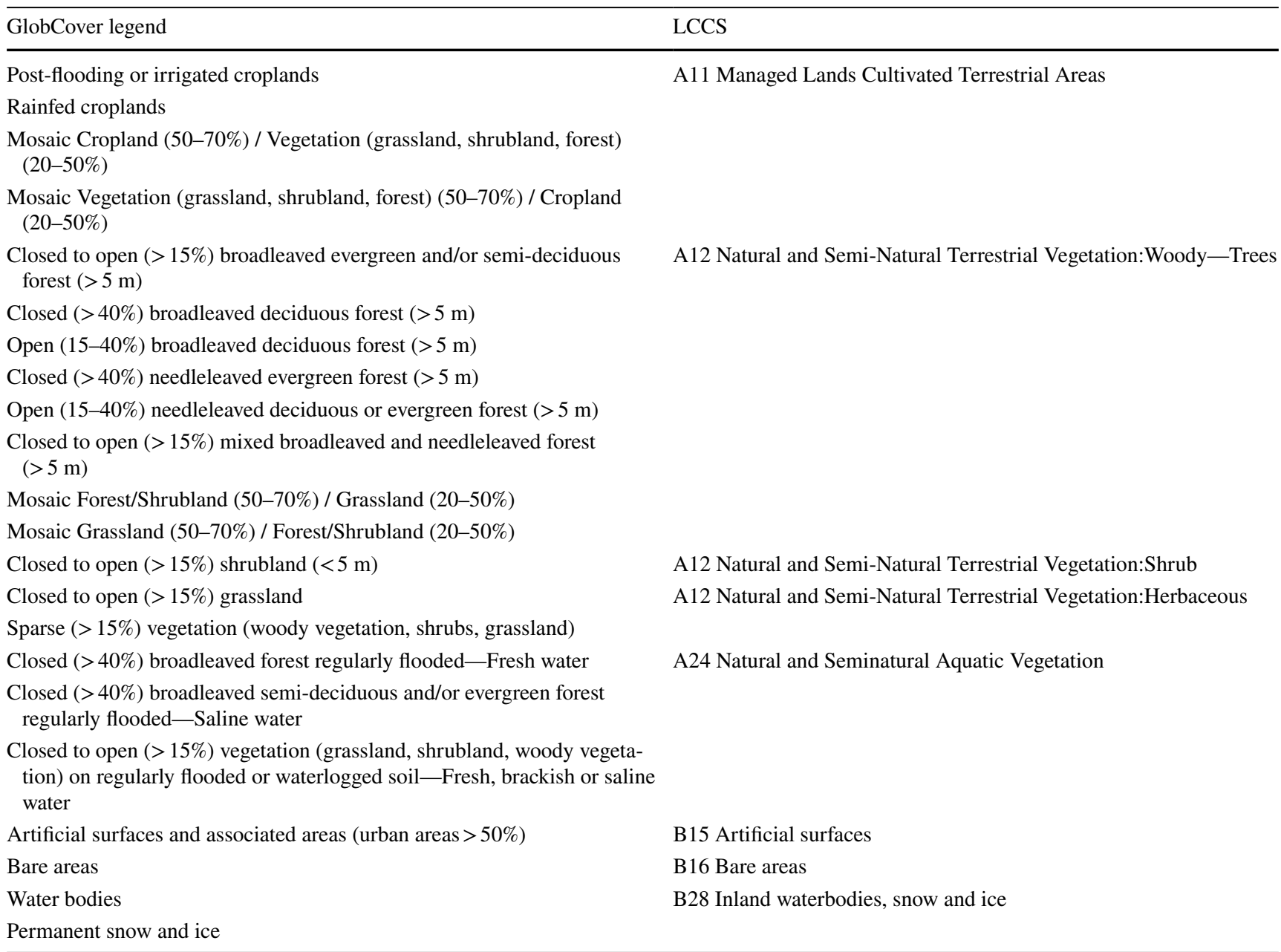

Table 4 Data freely available from published databases for Tier 1 application

\begin{tabular}{|c|c|c|c|c|c|c|}
\hline Data type & Data set & Extent & Data extension & Pixels size & $\mathrm{EPSG}^{\mathrm{a}}$ & Data source \\
\hline Morphological & DEM & global & GEOTIFF & $30 \times 30 \mathrm{~m}$ & 4326 & SRTM $^{\mathrm{b}}$ \\
\hline Geological & Vector & global & WFS & - & 4326 & GLIM $^{c}$ (Hartmann and Moosdorf 2012) \\
\hline Environmental & Raster & global & GEOTIFF & $300 \times 300 \mathrm{~m}$ & 4326 & (c) ESA 2010 and UCLouvain ${ }^{\mathrm{d}}$ \\
\hline PGA & Raster & global & GEOTIFF & $90 \times 90 \mathrm{~m}$ & 4326 & $\begin{array}{l}\text { CHRR-CIESIN }^{\mathrm{e}} \text { (CHRR-Columbia Uni- } \\
\text { versity, CIESIN-Columbia University } \\
\text { 2005) }\end{array}$ \\
\hline Precipitation & Raster & global & txt & $10 \times 10 \mathrm{~km}$ & 4326 & IMRG $^{f}$ (Huffman et al. 2019) \\
\hline Landslide inventory & Vector & global & shp & - & 4326 & NASA-COOLR $^{\mathrm{g}}$ (Kirschbaum et al. 2010) \\
\hline
\end{tabular}

${ }^{a}$ http://www.epsg-registry.org/, last accessed 2021-04-15

bhttps://cmr.earthdata.nasa.gov/search/concepts/C1000000240-LPDAAC_ECS.html, last accessed 2021-04-01

${ }^{\mathrm{c}}$ https://doi.pangaea.de/10.1594/PANGAEA.788537, last accessed 2021-04-15

${ }^{\mathrm{d}}$ http://due.esrin.esa.int/page_globcover.php, last accessed 2021-04-15

${ }^{\mathrm{e}} \mathrm{https}: / /$ sedac.ciesin.columbia.edu/data/set/ndh-earthquake-distribution-peak-ground-acceleration last accessed 2021-04-15

f https://disc.gsfc.nasa.gov/datasets/GPM_3IMERGDF_06/summary?keywords=\%22IMERG\%20final\%22 last accessed 2021-04-15

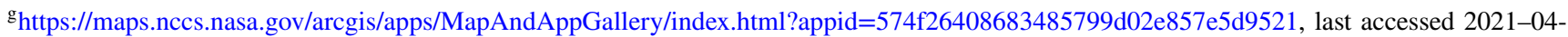
15 
to slope stability, respectively. The general formulations of Agterberg et al. (1989) are the following:

$W^{+}=\ln \frac{P(B \mid D)}{P\left(B \mid D_{1}\right)}$

$W^{-}=\ln \frac{P\left(B_{1} \mid D\right)}{P\left(B_{1} \mid D_{1}\right)}$

$W_{f}=W^{+}-W^{-}$

where $P$ is the probability, $B$ is the presence of a potential landslide causative factor, $B_{1}$ is the absence of a potential landslide causative factor, $D$ is the presence of a landslide and $D_{1}$ represents the absence of a landslide. $W f$ is called weight contrast: the magnitude of the contrast reflects the overall spatial relation between causative factors and landslides (Dahal et al. 2008).

The landslide susceptibility is mapped by the sum of $i t h$ weights contrast of the classified maps for the $n$ causative factors:

$L S I=\sum_{i=1}^{n} W_{f i}$

The result is the Landslide Susceptibility Index ( $L S I)$. Once standardized, it represents a measure of the landslide likelihood of occurrence or a measure of the potential spatial distribution of future landslides.

To evaluate the ability of the susceptibility model to predict the spatial distribution of the landslides and to evaluate the robustness of the model fitting capacity, the Area Under the Curve (AUC), calculated from the Receiving Operating Characteristic (ROC) curve (Chung and Fabbri 2003; Fawcett 2006), has been proposed. The ROC curve explores the relation between the True Positive Rate and the False Positive Rate by consecutive cutoffs of the LSI. Formally, each map-unit of the susceptibility map is labeled with True Positive ( $t p)$, False Positive $(f p)$, True Negative ( $t n)$ and False Negative $(f n)$ tags. In the susceptibility map, a map-unit is True or False according to the presence or the absence of landslides, respectively. Moreover, the unit is considered Positive or Negative if the relative susceptibility value is higher (stable unit) or lower (unstable unit) than the cutoff. The ROC curves are graphed coupling $t p_{\text {rate }}\left(y\right.$-axis) and $f p_{\text {rate }}(x$-axis):

$$
\begin{aligned}
& t p_{\text {rate }}=\frac{t p}{t p+f n} \\
& f p_{\text {rate }}=\frac{f p}{f p+t n}
\end{aligned}
$$

The area underlying the ROC curve (AUC) can be used as a metric to assess the overall quality of a model: the larger the area, the better the performance of the model over the whole range of possible cutoffs. Therefore, if the AUC is equal to 1 it means that the results are perfect, whereas if it is equal to 0.5 the scenario predicted is unlikely.

Considering the accuracy of the landslide inventory, the analysis has been conducted with the pixel size of $3 \mathrm{~km} \mathrm{x}$ $3 \mathrm{~km}$. Thus, the causative factors have been resampled to the same size before the statistical analysis. The categorical factors have been resampled taking into account the predominant class, while for the continuous factors, the average of the included values have been calculated. The landslide inventory has been divided randomly in two datasets: $70 \%$ and $30 \%$, to train and validate the model. The software used for the analysis are QGIS, SAGA-GIS. The simulation based on the WoE and the validation have been processed with the SZ-plugin (Titti and Sarretta 2020) developed for QGIS. The ROC analysis has been carried out using the Scikit-learn module (Pedregosa et al. 2011).

\section{Results and discussion}

The landslide susceptibility map, resulting from the analysis, is shown in Fig. 8a and the class weights are reported in Table 5.

The WoE is a bivariate approach which evaluates the single predisposing factor in relation with the dependent variable, Table 5 reports the $W^{+}, W^{-}, W_{f}$ values and the percentage of landslide cells and area of each class factor. The weight contrasts of slope factor show an almost constant increase in instability from $0^{\circ}$ to $>30^{\circ}$, with a peak around $21^{\circ}-30^{\circ}$ and a negative value between slope angle of $7^{\circ}$ and $15^{\circ}$. Noticeably, the mask until $7^{\circ}$ of slope adopted for the factors has excluded the first three classes of the slope factor, since their cell value is equal to the average of $30 \mathrm{~m}$ slope. Even though the pixel size of the analysis cannot perfectly describe the land surface morphology, the trend of the $W_{f}$ is realistic. Moreover, the highest number of landslides is present in the class $21^{\circ}-30^{\circ}$, which includes the $52 \%$ of the landslide cells, revealing the highest $W_{f}$ of the slope factor. The slope factor also includes the most stable class of all factors which is the class $7^{\circ}-10^{\circ}$ with $W_{f}$ equal to -6 .

Plan and profile curvatures represent the convexity and concavity of the surface tangent to the contour line and to the slope line, respectively. The former is related to the lateral flow convergence or divergence, while the second to the acceleration and deceleration of a flow along the gravity direction. Based on the $W_{f}$ values of these factors, there is not a relevant difference between them. The landslides percentage per class and the area percentage are very balanced. (Table 5). 


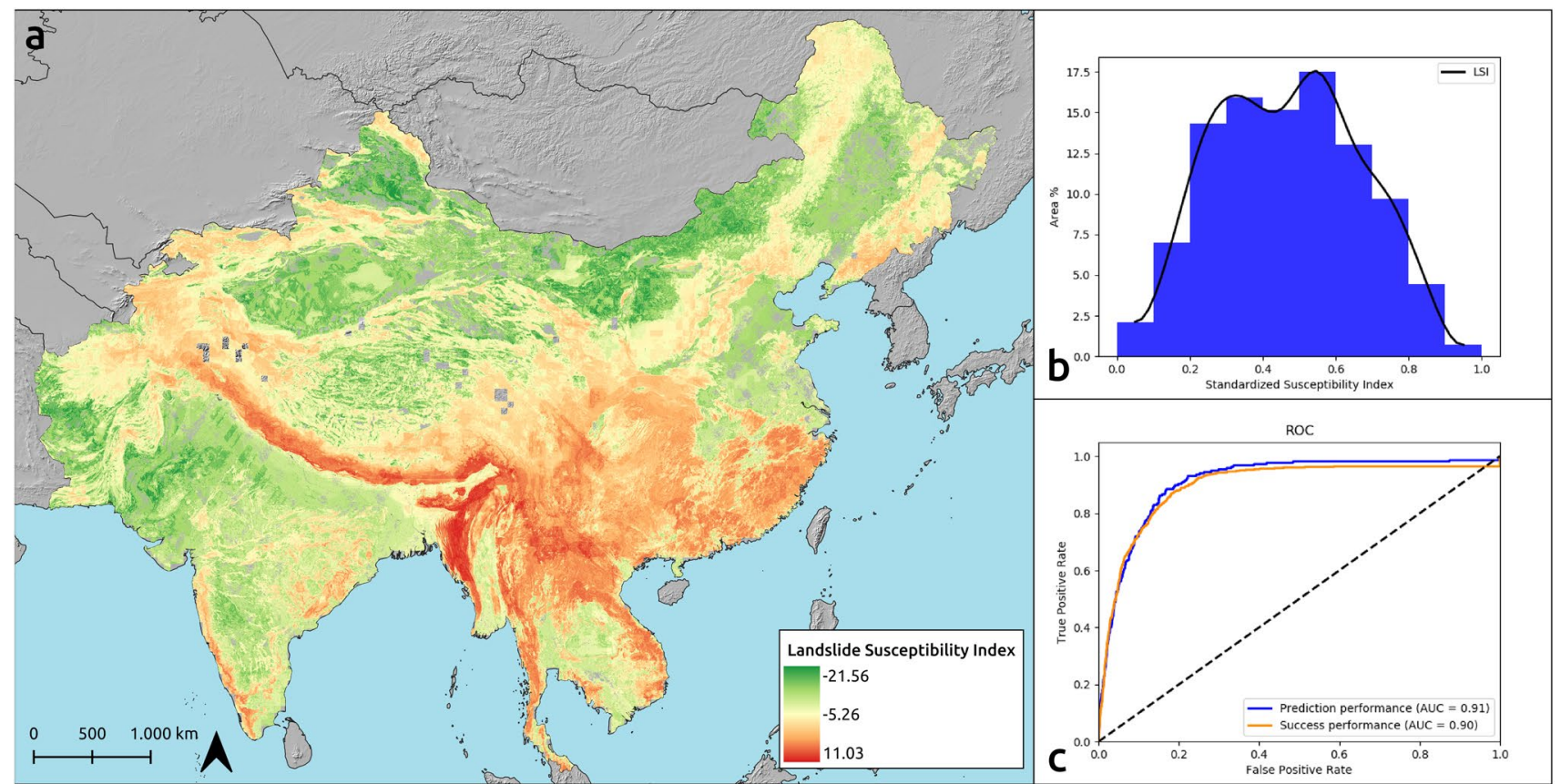

Fig. 8 a $3 \times 3 \mathrm{~km}$ landslide susceptibility map of south-Asia. b Spatial distribution of the LSI. c Prediction rate curve and Success rate curve of the landslide susceptibility map

The relative relief presents an increasing trend from $18 \mathrm{~m}$ to $>625 \mathrm{~m}$. Since the classes represent deciles, the area of each class is almost $10 \%$ of the total. Therefore, the trend of the $W_{f}$ is dependent on the landslide included. The most unstable classes are the 424-625 $\mathrm{m}$ and $>625$ which include the $58 \%$ of the total landslide cells (Table 5).

As regards the lithology factor, the results confirm that $W_{f}$ parameters must be analyzed in relation to the other classes and with reference to the specific study area. Indeed, depending on the geological context, some unconsolidated lithologies might have lower strengths compared to metamorphic ones. Here, "unconsolidated sediment" is the most stable class, while "metamorphic rocks" is the least stable. In particular, the stability of the former comes from the high extension of the area (31\% of the total area), although it includes the $10 \%$ of the landslide cells, while the instability of the latter is due to the balance between the number of landslides included (15\% of the total landslide cells) and the area covered by the class (7\% of the total). The second highest $W_{f}$ is the "sedimentary rocks" which covers about $42 \%$ of the total area and the $60 \%$ of the landslide cells (Table 5).

Regarding the land cover, it contains one of the most stable classes and the most unstable class of all considered factors. Indeed, the land covered by "shrub" reflects a $W_{f}$ value equal to 2.35 , while "bare areas" display the lowest value, equal to -3.77 (Table 5).

The $W_{f}$ values of the PGA and precipitation classes reveal that the landslides included in the inventory are mainly triggered by precipitation (Fig. 3). The PGA $W_{f}$ are variable between -1.57 and 2.01 without a precise trend. The precipitation classes have an increasing trend similar to relief and slope. The higher the annual precipitation, the higher the instability up to a $W_{f}$ value of 2.55 .

The standardized LSI $(0-1)$ has been divided into 5 classes (Fig. 9) to fit the success curve as best as possible: 0-0.54 "very low", 0.54-0.64 "low", 0.64-0.74 "moderate", 0.74-0.80 "high", 0.80-1 "very high". Statistically, in the 5-classes susceptibility map (Fig. 9a), the highly susceptible terrain covers 5\% (Fig. 9b) of the total mapped area, more than the $93 \%$ of that is steeper than $15^{\circ}$ and the $92 \%$ has a relief higher than $194 \mathrm{~m}$. On the contrary, the $68 \%$ of the "very low" susceptibility areas, which cover the $68 \%$ (Fig. 9b) of the study area, respectively, has a relief lower than $120 \mathrm{~m}$ (87\% lower than $288 \mathrm{~m})$.

The weights $W^{+}$and $W^{-}$are calculated from the relation between the number of landslides included or excluded into the class factor and the size area of the class factor. The result of the difference between $W^{+}$and $W^{-}$plays a significant role to determine if the specific class is favorable to the instability of the slope. In particular, the areas represented by negative $W_{f}$ values can be considered stable and the areas represented by positive $W_{f}$ values, unstable with respect to a specific predisposing factor. Therefore, the LSI resulting from the sum of the $W_{f}$ may range 
Table 5 Positive weights, negative weights and contrast weights of the classified causative factors resulting from the WoE analysis of the study area

\begin{tabular}{|c|c|c|c|c|c|c|}
\hline Causative factors & Classes & $W^{+}$ & $W^{-}$ & $W_{f}$ & Landslides (\%) & Area $(\%)$ \\
\hline \multirow[t]{8}{*}{ Slope $\left(^{\circ}\right)$} & 0 & - & - & - & - & - \\
\hline & $1-3$ & - & - & - & - & - \\
\hline & $4-6$ & - & - & - & - & - \\
\hline & $7-10$ & -5.55 & 0.46 & -6.01 & 0.14 & 36.78 \\
\hline & $11-15$ & -1.10 & 0.14 & -1.24 & 6.27 & 18.74 \\
\hline & $16-20$ & 0.08 & -0.01 & 0.09 & 13.96 & 12.90 \\
\hline & $21-30$ & 0.94 & -0.51 & 1.44 & 52.14 & 20.43 \\
\hline & $>30$ & 0.90 & -0.20 & 1.11 & 27.49 & 11.15 \\
\hline \multirow[t]{5}{*}{ Plan curvature } & $<1.310^{-7}$ & -0.28 & 0.06 & -0.33 & 15.10 & 19.93 \\
\hline & $1.310^{-7}-1.210^{-4}$ & 0.30 & -0.09 & 0.39 & 27.07 & 20.09 \\
\hline & $1.210^{-4}-2.210^{-4}$ & 0.16 & -0.04 & 0.20 & 23.50 & 20.05 \\
\hline & $2.210^{-4}-3.810^{-4}$ & 0.10 & -0.03 & 0.13 & 22.22 & 20.02 \\
\hline & $>3.810^{-4}$ & -0.50 & 0.09 & -0.59 & 12.11 & 19.92 \\
\hline \multirow[t]{5}{*}{ Profile curvature } & $<-2.610^{-4}$ & 0.16 & -0.04 & 0.20 & 23.50 & 20.01 \\
\hline & $-2.610^{-4}$ to $-1.410^{-4}$ & 0.18 & -0.05 & 0.24 & 24.07 & 20.02 \\
\hline & $-1.410^{-4}$ to $-5.410^{-5}$ & -0.11 & 0.03 & -0.14 & 17.95 & 20.04 \\
\hline & $-5.410^{-5}$ to $4.210^{-5}$ & -0.09 & 0.02 & -0.01 & 18.38 & 20.04 \\
\hline & $>4.210^{-5}$ & -0.21 & 0.05 & -0.25 & 16.10 & 19.89 \\
\hline \multirow[t]{10}{*}{ Relief (m) } & $0-9$ & 0.00 & 0.11 & -0.11 & 0.00 & 10.50 \\
\hline & $9-18$ & 0.00 & 0.10 & -0.10 & 0.00 & 9.46 \\
\hline & $18-34$ & -4.22 & 0.10 & -4.33 & 0.14 & 9.74 \\
\hline & $34-65$ & -1.95 & 0.09 & -2.04 & 1.42 & 10.05 \\
\hline & $65-120$ & -0.86 & 0.06 & -0.92 & 4.27 & 10.10 \\
\hline & $120-194$ & -0.29 & 0.03 & -0.32 & 7.41 & 9.92 \\
\hline & $194-288$ & 0.08 & -0.01 & 0.09 & 10.83 & 10.00 \\
\hline & $288-424$ & 0.50 & -0.07 & 0.57 & 16.52 & 10.05 \\
\hline & $424-625$ & 1.17 & -0.29 & 1.46 & 32.48 & 10.07 \\
\hline & $>625$ & 0.98 & -0.21 & 1.18 & 26.92 & 10.12 \\
\hline \multirow[t]{7}{*}{ Lithology } & Unconsolidated sediment & -1.10 & 0.27 & -1.37 & 10.40 & 31.40 \\
\hline & Volcanic rocks & -0.89 & 0.05 & -0.94 & 3.42 & 8.31 \\
\hline & Sedimentary rocks & 0.35 & -0.37 & 0.72 & 60.54 & 42.64 \\
\hline & Plutonic rocks & 0.02 & -0.00 & 0.02 & 10.11 & 9.88 \\
\hline & Metamorphic rocks & 0.78 & -0.09 & 0.87 & 15.53 & 7.17 \\
\hline & Ice, Glaciers and Water & 0.00 & 0.00 & 0.00 & 0.00 & 0.40 \\
\hline & Evaporites & 0.00 & 0.00 & 0.00 & 0.00 & 0.20 \\
\hline \multirow[t]{8}{*}{ Land cover } & Cultivated areas & -0.56 & 0.25 & -0.81 & 22.79 & 39.81 \\
\hline & Woody/trees & 0.69 & -0.21 & 0.90 & 31.77 & 15.87 \\
\hline & Shrub & 1.92 & -0.42 & 2.35 & 38.32 & 5.62 \\
\hline & Herbaceous & -1.69 & 0.11 & -1.79 & 2.28 & 12.30 \\
\hline & Aquatic vegetation & 0.00 & 0.00 & 0.00 & 0.00 & 0.07 \\
\hline & Artificial surfaces & 2.08 & -0.03 & 2.11 & 3.42 & 0.43 \\
\hline & Bare areas & -3.51 & 0.26 & -3.77 & 0.71 & 23.77 \\
\hline & Water/snow/ice & -1.10 & 0.01 & -1.11 & 0.71 & 2.13 \\
\hline
\end{tabular}


Table 5 (continued)

\begin{tabular}{|c|c|c|c|c|c|c|}
\hline Causative factors & Classes & $W^{+}$ & $W^{-}$ & $W_{f}$ & Landslides (\%) & Area (\%) \\
\hline \multirow[t]{11}{*}{ PGA (deciles) } & $0^{\text {th }}$ & -0.54 & 1.03 & -1.57 & 47.29 & 81.21 \\
\hline & $1^{\text {th }}$ & -0.60 & 0.01 & -0.61 & 1.00 & 1.83 \\
\hline & $2^{\text {th }}$ & -0.24 & 0.0035 & -0.25 & 1.28 & 1.63 \\
\hline & $3^{\text {th }}$ & 0.53 & -0.01 & 0.54 & 3.13 & 1.84 \\
\hline & $4^{\text {th }}$ & 1.66 & -0.07 & 1.74 & 8.69 & 1.65 \\
\hline & $5^{\text {th }}$ & 1.18 & -0.04 & 1.23 & 5.70 & 1.74 \\
\hline & $6^{\text {th }}$ & 1.00 & -0.023 & 1.03 & 4.56 & 1.68 \\
\hline & $7^{\text {th }}$ & 1.47 & -0.06 & 1.54 & 7.98 & 1.83 \\
\hline & $8^{\text {th }}$ & 1.90 & -0.11 & 2.01 & $12 . .25$ & 1.84 \\
\hline & $9^{\text {th }}$ & 1.01 & -0.04 & 1.05 & 5.56 & 2.02 \\
\hline & $10^{\text {th }}$ & -0.06 & 0.001 & -0.06 & 2.56 & 2.71 \\
\hline \multirow[t]{10}{*}{ Precipitation $(\mathrm{mm} / \mathrm{y})$} & $0-111$ & 0 & 0.10 & -0.10 & 0.00 & 9.96 \\
\hline & $111-217$ & -3.55 & 0.10 & -3.65 & 0.28 & 9.95 \\
\hline & $217-339$ & -3.55 & 0.10 & -3.65 & 0.28 & 9.94 \\
\hline & $339-478$ & -1.84 & 0.09 & -1.93 & 1.57 & 9.85 \\
\hline & $478-605$ & -2.06 & 0.09 & -2.15 & 1.28 & 10.02 \\
\hline & $605-769$ & -2.86 & 0.1 & -2.96 & 0.57 & 9.93 \\
\hline & $769-1003$ & -0.81 & 0.06 & -0.87 & 4.42 & 9.94 \\
\hline & $1003-1340$ & 0.22 & -0.03 & 0.24 & 12.68 & 10.21 \\
\hline & $1340-1731$ & 0.67 & -0.11 & 0.79 & 19.80 & 10.08 \\
\hline & $>1731$ & 1.77 & -0.79 & 2.55 & 59.12 & 10.11 \\
\hline
\end{tabular}

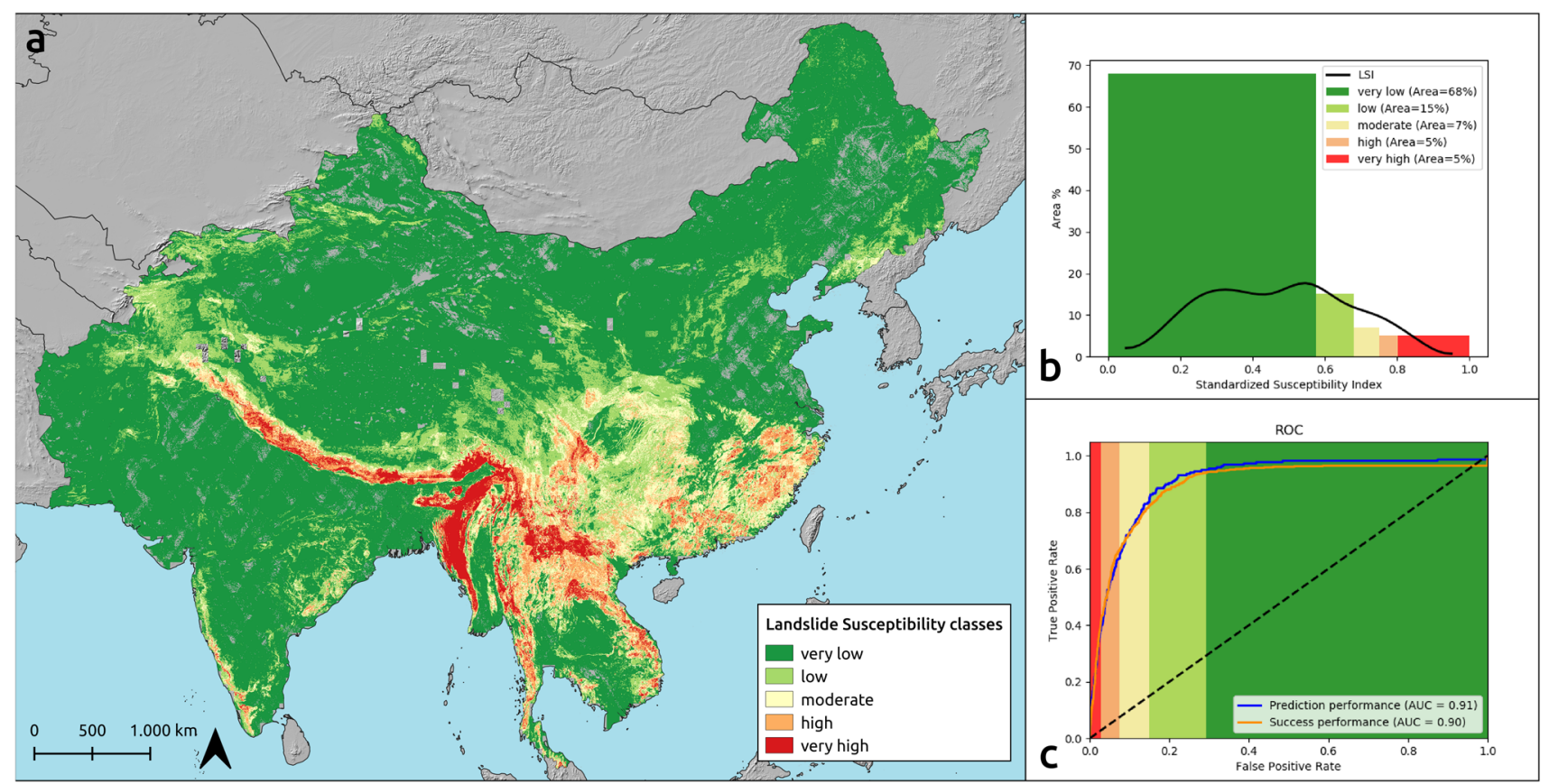

Fig. 9 a Classified $3 \times 3 \mathrm{~km}$ landslide susceptibility map of south-Asia. b Spatial distribution of the LSI and the area covered by the relative classes. $\mathbf{c}$ Prediction rate curve and Success rate curve of the landslide susceptibility map 
Fig. 10 Landslide susceptibility map based on administrative units

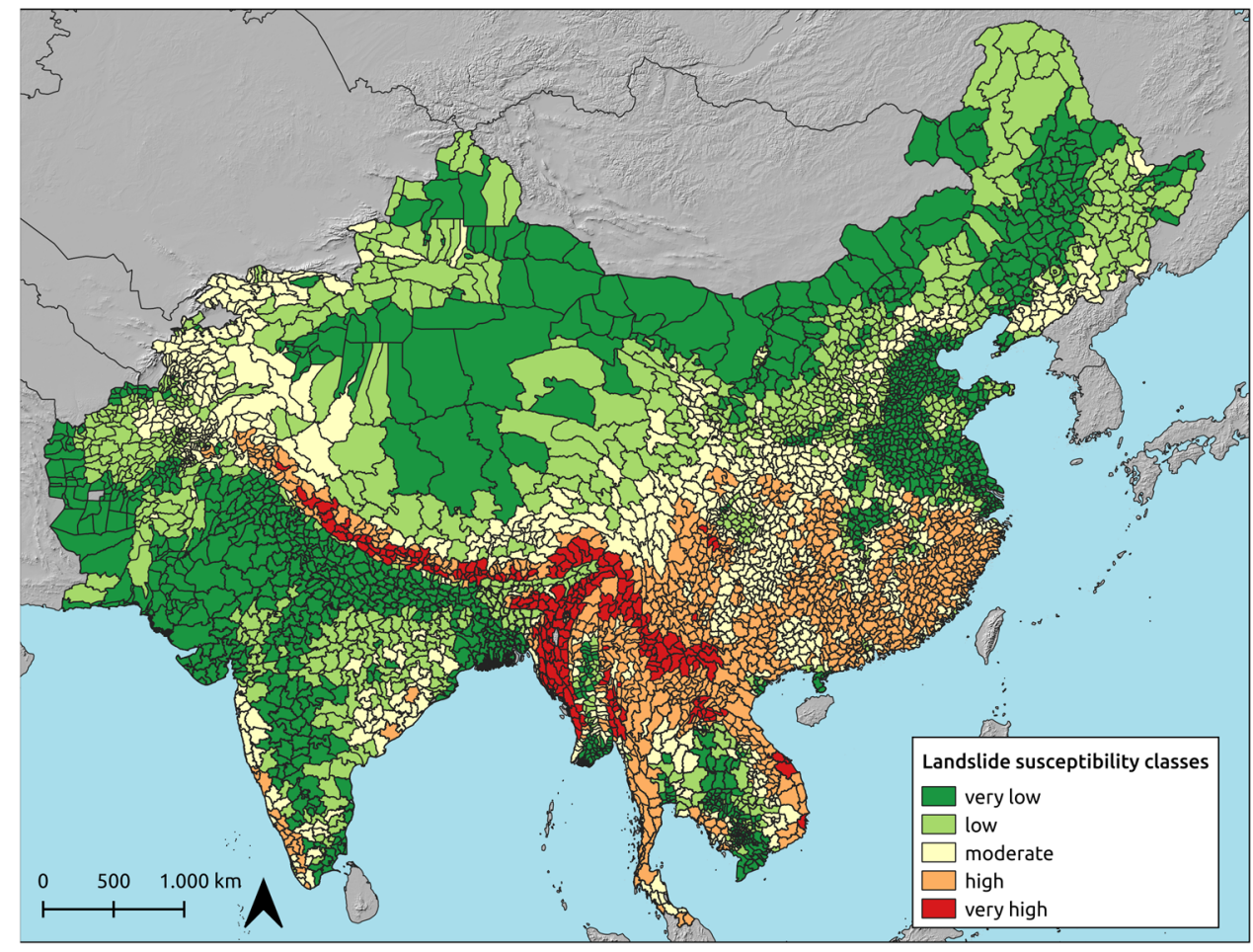

between negative and positive values which allow for evaluating the stability or instability of the area.

To select the most susceptible area to analyze in detail in the Tier 2 assessment, a susceptibility class has been assigned to each administration unit of the study area. Different levels of administration units are available in GADM website. ${ }^{1}$ Since different levels are available for different countries, a specific level has been assigned to each country to homogenize the dimension of the administration units all over the study area. Taking inspiration from Arup (2020) the relative landslide susceptibility of the single administrative unit has been evaluated as the 80th percentile of the LSI pixel-based map (Fig. 8) and then classified from very low to very high to optimize the ROC curve weighted over the extension area of the administrative units area. The result is shown in Fig. 10.

The prediction performance and the success of the Tier 1 analysis have been evaluated by the ROC curves (Fawcett, 2006), which are reported in Fig. 9c. The curves have been plotted using the validation dataset and the training data set, respectively. The resulting AUC is equal to 0.91 for the prediction curve and equal to 0.90 for the success curve. Overall, the model applied to the selected study area has demonstrated good reliability to evaluate potential instability areas.

\footnotetext{
${ }^{1}$ https://gadm.org/data.html last access, 2021-04-18.
}

An additional way to evaluate the prediction capacity of the model is presented in Fig. 11. It compares the ROC curve of the single causative factor with the curve of the landslide susceptibility map. The significant differences among the ROC curve of the susceptibility map $(\mathrm{AUC}=0.91)$ and the curve of the slope $(\mathrm{AUC}=0.77)$, relief $(A U C=0.77)$, precipitation $(A U C=0.90)$ along with the lower values of the AUC of the other causative factors, confirm the goodness of the prediction performance based on the combination of multiple factors (slope, curvatures,

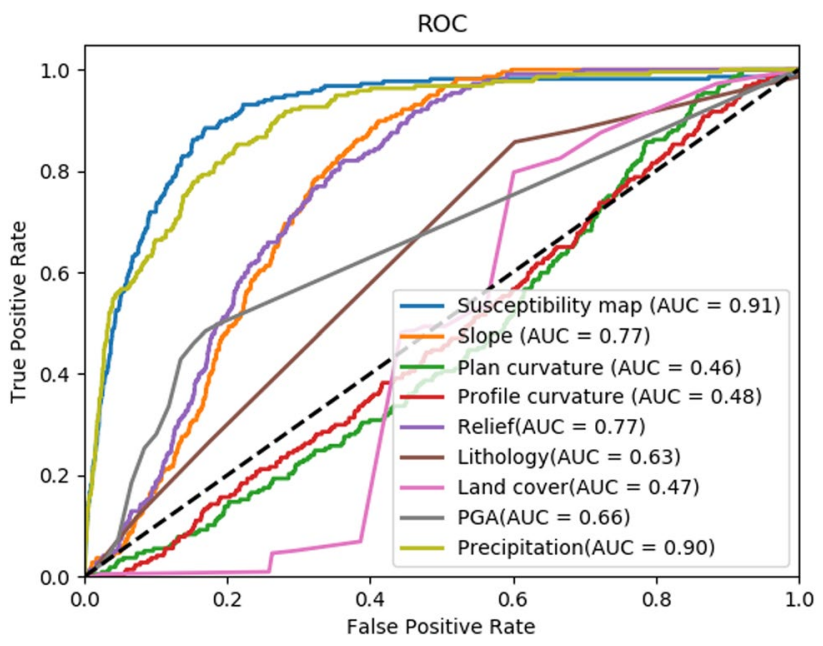

Fig. 11 ROC curves and relative prediction performances (AUC) of the causative factors and of the susceptible map 
relief, land cover, lithology, PGA and precipitation) in comparison with the use of single factor alone (Günther et al. 2013b; Remondo et al. 2003). The factors that appear to play a major role in predisposing slope instability phenomena with respect to the landslide inventory used are slope, relief and precipitation.

\section{Conclusions}

The work is aimed to map the landslide susceptibility in the Belt and Road Countries. In this framework, the landslide susceptibility zoning through the multi-Tier approach has been carried out.

The landslide susceptibility map of south-Asia has been modeled using a quantitative, statistical method. Eight independent variables, i.e., Slope, Plan curvature, Profile curvature, Relative relief, Lithology, Land cover, PGA, Precipitation, have been classified and then weighted by the WoE. The analysis has been based on the NASACOOLR landslides inventory. It is a global landslides cata$\log$ that collects data from online media reports, disaster databases, scientific reports, citizen reports, and others. All the data and software used in this work are open and open-source.

The result is a 5 classes landslide susceptibility map. The ability of the susceptibility model to predict the spatial distribution of the landslides and the goodness of the model fitting have been evaluated by the comparison of the ROC curves calculated from the validating and training datasets. The prediction and success performance are 0.91 and 0.90 , respectively. Among the causal factors slope, relief and precipitation play a major role. The administrative units, displaying moderate to very high susceptibility class, have been selected for further analysis to be carried out at a national scale (Tier 2).

\begin{abstract}
Acknowledgements The work has been funded by the CNR-IRPI in the context of the Sino-Italian Laboratory on Geological and Hydrological Hazards (CUP-B96J16001430005) between the National Research Council of Italy (CNR-IRPI) and the Chinese Academy of Sciences (CAS-IMHE). Land cover data have been extracted from ESA GlobCover 2009 Project, filled DEM from CIAT, geological data from USGS-GSC and the landslide inventory from NASA-COOLR. The SZ-plugin is available in the repository: https://github.com/CNR-IRPIPadova/SZ. The GEE code for data pre-processing is in the repository: https://github.com/giactitti/GEE_TAGEE_terrain_analysis. GT, LB wrote the paper, GT produced the figures, designed and implemented the model of the analysis, ran the simulations. GT, LB conceived the analysis. LB, QZ, AP and PC revised the paper.
\end{abstract}

Funding Open access funding provided by Alma Mater Studiorum Università di Bologna within the CRUI-CARE Agreement.

\section{Declarations}

Conflict of interest The authors declare no conflicts of interest and no ethical issues.

Open Access This article is licensed under a Creative Commons Attribution 4.0 International License, which permits use, sharing, adaptation, distribution and reproduction in any medium or format, as long as you give appropriate credit to the original author(s) and the source, provide a link to the Creative Commons licence, and indicate if changes were made. The images or other third party material in this article are included in the article's Creative Commons licence, unless indicated otherwise in a credit line to the material. If material is not included in the article's Creative Commons licence and your intended use is not permitted by statutory regulation or exceeds the permitted use, you will need to obtain permission directly from the copyright holder. To view a copy of this licence, visit http://creativecommons.org/licenses/by/4.0/.

\section{References}

Agterberg FP, Bonham-Carter GF, Wright DF (1989) Weights of evidence modelling: a new approach to mapping mineral potential. In: Agterberg FP, Bonham-Carter GF (eds) Statistical applications in the earth sciences. Geological Survey Canada Paper, Windsor, pp 171-183

Arup (2020) The Global Landslide Hazard MapFinal Project Report. The World Bank. https://development-data-hub-s3-public.s3. amazonaws.com/ddhfiles/1191621/global-landslide-hazard-mapreport.pdf. Accessed 15 Apr 2021

Axing ZHU, Tao PEI, Ping QJ, Yongbo C, Chenghu Z, Qiangguo CAI, Axing ZHU, Tao PEI, Ping QJ, Yongbo C, Chenghu Z, Qiangguo CAI (2010) A landslide susceptibility mapping approach using expert knowledge and fuzzy logic under GIS, a landslide susceptibility mapping approach using expert knowledge and fuzzy logic under GIS. Progress Geogr 25:1-12. https://doi.org/10.11820/ dlkxjz.2006.04.001

Ayalew L, Yamagishi H, Ugawa N (2004) Landslide susceptibility mapping using GIS-based weighted linear combination, the case in Tsugawa area of Agano River, Niigata Prefecture, Japan. Landslides 1:73-81. https://doi.org/10.1007/s10346-003-0006-9

Barredo JI, Benavides A, Hervás J, van Westen CJ (2000) Comparing heuristic landslide hazard assessment techniques using GIS in the Tirajana basin, Gran Canaria Island, Spain. Int J Appl Earth Obs Geoinf 2:9-23. https://doi.org/10.1016/S0303-2434(00)85022-9

Bonham-Carter GF, Agterberg FP, Wright DF (1988) Integration of geological datasets for gold exploration in Nova Scotia. Photogram Eng Remote Sens 54:1585-1592

Bontemps S, Defourny P, Van Bogaert E, Arino O, Kalogirou V, Perez JR (2011) GLOBCOVER 2009, Product description and validation report

Broeckx J, Vanmaercke M, Duchateau R (2018) A data-based landslide susceptibility map of Africa. Earth Sci Rev 185:102-121. https:// doi.org/10.1016/j.earscirev.2018.05.002

Bui DT, Tuan TA, Klempe H, Pradhan B, Revhaug I (2016) Spatial prediction models for shallow landslide hazards: a comparative assessment of the efficacy of support vector machines, artificial neural networks, kernel logistic regression, and logistic model tree. Landslides 13:361-378. https://doi.org/10.1007/ s10346-015-0557-6

Carrara A, Crosta G, Frattini P (2008) Comparing models of debrisflow susceptibility in the alpine environment. Geomorphol GIS Technol Models Assess Landslide Hazard Risk 94:353-378. https://doi.org/10.1016/j.geomorph.2006.10.033 
Catani F, Lagomarsino D, Segoni S, Tofani V (2013) Landslide susceptibility estimation by random forests technique: sensitivity and scaling issues. Nat Hazards Earth Syst Sci 13:2815-2831. https:// doi.org/10.5194/nhess-13-2815-2013

CHRR-Columbia University, CIESIN-Columbia University (2005) Global earthquake hazard distribution: peak ground acceleration. NASA Socioeconomic Data and Applications Center (SEDAC), Palisades

Chacón J, Irigaray C, Fernández T, Hamdouni RE (2006) Engineering geology maps: landslides and geographical information systems. Bull Eng Geol Environ 65:341-411. https://doi.org/10.1007/ s10064-006-0064-z

Chen W, Chai H, Sun X, Wang Q, Ding X, Hong H (2016) A GISbased comparative study of frequency ratio, statistical index and weights-of-evidence models in landslide susceptibility mapping. Arab J Geosci 9:204. https://doi.org/10.1007/s12517-015-2150-7

Chen W, Xie X, Wang J, Pradhan B, Hong H, Bui DT, Duan Z, Ma J (2017) A comparative study of logistic model tree, random forest, and classification and regression tree models for spatial prediction of landslide susceptibility. CATENA 151:147-160. https://doi.org/ 10.1016/j.catena.2016.11.032

Chung C-JF, Fabbri AG (2003) Validation of spatial prediction models for landslide hazard mapping. Nat Hazards 30:451-472. https:// doi.org/10.1023/B:NHAZ.0000007172.62651.2b

Constantin M, Bednarik M, Jurchescu MC, Vlaicu M (2011) Landslide susceptibility assessment using the bivariate statistical analysis and the index of entropy in the Sibiciu Basin (Romania). Environ Earth Sci 63:397-406. https://doi.org/10.1007/s12665-010-0724-y

Corominas J, van Westen C, Frattini P, Cascini L, Malet J-P, Fotopoulou S, Catani F, Van Den Eeckhaut M, Mavrouli O, Agliardi F, Pitilakis K, Winter MG, Pastor M, Ferlisi S, Tofani V, Hervás J, Smith JT (2014) Recommendations for the quantitative analysis of landslide risk. Bull Eng Geol Environ 73:209-263. https://doi. org/10.1007/s10064-013-0538-8

Cui P, Amar DR, Zou Q, Lei Y, Chen X, Cheng D (2017) Natural Hazards and disaster risk in one belt one road corridors. Advancing culture of living with landslides-volume 2 advances in landslide science. Springer, Berlin, pp 1155-1164. https://doi.org/10.1007/ 978-3-319-53498-5_131

Dahal RK, Hasegawa S, Nonomura A, Yamanaka M, Masuda T, Nishino K (2008) GIS-based weights-of-evidence modelling of rainfall-induced landslides in small catchments for landslide susceptibility mapping. Environ Geol 54:311-324. https://doi.org/10. 1007/s00254-007-0818-3

Dalia K, Thomas S (2018) Satellite-based assessment of rainfall-triggered landslide hazard for situational awareness. Earth's Future 6:505-523. https://doi.org/10.1002/2017EF000715

Di Gregorio A (2016) Land cover classification system: classification concepts. FAO, Rome

Dilley M, Chen RS, Deichmann U, Lerner-Lam AL, Arnold M (2005) Natural disaster hotspots: a global risk analysis. World Bank, Washington, D.C. https://openknowledge.worldbank.org/handle/ $10986 / 7376$

EC (2006) Thematic strategy for soil protection. COM(2006)231 final

Eckelmann W, Baritz R, Bialousz S, Bielek P, Carre F, Houšková B, Jones RJA, Kibblewhite MG, Kozak J, Bas CL, Tóth G, Tóth T, Várallyay G, Yli HM, Zupan M (2006) Common criteria for risk area identification according to soil threats. European Soil Bureau Research Report No. 20, EUR 22185 EN. Office for Official Publications of the European Communities, Luxembourg.

Eeckhaut MVD, Hervás J, Jaedicke C, Malet J-P, Montanarella L, Nadim F (2012) Statistical modelling of Europe-wide landslide susceptibility using limited landslide inventory data. Landslides 9:357-369. https://doi.org/10.1007/s10346-011-0299-z

Farr TG, Rosen PA, Caro E, Crippen R, Duren R, Hensley S, Kobrick M, Paller M, Rodriguez E, Roth L, Seal D, Shaffer S, Shimada
J, Umland J, Werner M, Oskin M, Burbank D, Alsdorf D (2007) The shuttle radar topography mission. Rev Geophys. https://doi. org/10.1029/2005RG000183

Fawcett T (2006) An introduction to ROC analysis. Pattern Recognit Lett 27:861-874. https://doi.org/10.1016/j.patrec.2005.10.010

Fell R, Corominas J, Bonnard C, Cascini L, Leroi E, Savage WZ (2008) Guidelines for landslide susceptibility, hazard and risk zoning for land use planning. Eng Geol 102:85-98. https://doi.org/10.1016/j. enggeo.2008.03.022

Florinsky V, Skrypitsyna TN, Trevisani S, Romaikin SV (2019) Statistical and visual quality assessment of nearly-global and continental digital elevation models of Trentino, Italy. Remote Sens Lett 10:726-735. https://doi.org/10.1080/2150704X.2019.1602790

Glade T, Crozier MJ (2012) A review of scale dependency in landslide hazard and risk analysis. Landslide hazard and risk. Wiley Online Books, New Jersey, pp 78-138. https://doi.org/10.1002/ 9780470012659.ch3

Goetz JN, Guthrie RH, Brenning A (2011) Integrating physical and empirical landslide susceptibility models using generalized additive models. Geomorphology 129:376-386. https://doi.org/10. 1016/j.geomorph.2011.03.001

Gorelick N, Hancher M, Dixon M, Ilyushchenko S, Thau D, Moore R (2017) Google earth engine: planetary-scale geospatial analysis for everyone. Remote Sens Environ Big Remot Sens Data 202:18 27. https://doi.org/10.1016/j.rse.2017.06.031

Gorsevski P, Gessler P, Foltz BR (2000) Spatial prediction of landslide hazard using discriminant analysis and GIS

Gorsevski PV, Gessler PE, Boll J, Elliot WJ, Foltz RB (2006) Spatially and temporally distributed modeling of landslide susceptibility. Geomorphology 80:178-198. https://doi.org/10.1016/j.geomorph. 2006.02.011

Günther A, Reichenbach P, Guzzetti F, Richter A (2007) Criteria for the identification of landslide risk areas in Europe: the Tier 1 approach. Guidelines for mapping areas at risk of landslides in Europe. Institute for Environment and Sustainability Joint Research Centre, Rome, pp 37-39

Günther A, Eeckhaut MVD, Reichenbach P, Hervás J, Malet J-P, Foster C, Guzzetti F (2013a) New developments in harmonized landslide susceptibility mapping over Europe in the framework of the European soil thematic strategy. Landslide science and practice. springer, Berlin, pp 297-301. https://doi.org/10.1007/978-3-64231325-7_39

Günther A, Reichenbach P, Malet J-P, Eeckhaut MVD, Hervás J, Dashwood C, Guzzetti F (2013b) Tier-based approaches for landslide susceptibility assessment in Europe. Landslides 10:529-546. https://doi.org/10.1007/s10346-012-0349-1

Günther A, Hervás J, Eeckhaut MVD, Malet J-P, Reichenbach P (2014) Synoptic pan-European landslide susceptibility assessment: the ELSUS 1000 v1 map. Landslide science for a safer geoenvironment. Springer, Cham, pp 117-122. https://doi.org/10.1007/9783-319-04999-1_12

Guzzetti F, Reichenbach P, Ardizzone F, Cardinali M, Galli M (2006) Estimating the quality of landslide susceptibility models. Geomorphology 81:166-184. https://doi.org/10.1016/j.geomorph. 2006.04.007

Guzzetti F, Mondini AC, Cardinali M, Fiorucci F, Santangelo M, Chang K-T (2012) Landslide inventory maps: new tools for an old problem. Earth Sci Rev 122:42-66. https://doi.org/10.1016/j. earscirev.2012.02.001

Hartmann J, Moosdorf N (2012) The new global lithological map database GLiM: a representation of rock properties at the Earth surface. Geochem Geophys Geosyst. https://doi.org/10.1029/2012G $\mathrm{C} 004370$

Hervás J (2007) Guidelines for mapping areas at risk of landslides in europe. Inst Environ Sustain Jt Res Centre. https://doi.org/10. $2788 / 63147$ 
Hong Y, Adler R, Huffman G (2007) Use of satellite remote sensing data in the mapping of global landslide susceptibility. Nat Hazards 43:245-256. https://doi.org/10.1007/s11069-006-9104-z

Huffman GJ, Stocker EF, Bolvin DT, Nelkin EJ, Jackson T (2019), GPM IMERG Final Precipitation L3 1 day 0.1 degree x 0.1 degree V06, Edited by Andrey Savtchenko, Greenbelt, MD, Goddard Earth Sciences Data and Information Services Center (GES DISC) Accessed 15 Apr 2021. https://doi.org/10.5067/GPM/ IMERGDF/DAY/06

Juang CS, Stanley TA, Kirschbaum DB (2019) Using citizen science to expand the global map of landslides: Introducing the Cooperative Open Online Landslide Repository (COOLR). PLoS ONE 14:e0218657. https://doi.org/10.1371/journal.pone.0218657

Kirschbaum DB, Adler R, Hong Y, Hill S, Lerner-Lam A (2010) A global landslide catalog for hazard applications: method, results, and limitations. Nat Hazards 52:561-575. https://doi.org/10.1007/ s11069-009-9401-4

Kirschbaum D, Stanley T, Zhou Y (2015) Spatial and temporal analysis of a global landslide catalog. Geomorphol Geohazard Databases 249:4-15. https://doi.org/10.1016/j.geomorph.2015.03.016

Kirschbaum D, Stanley T (2018) Satellite-based assessment of rainfalltriggered landslide hazard for situational awareness. Earth Future 6:505-523. https://doi.org/10.1002/2017EF000715

Lei Y, Peng C, Regmi AD, Murray V, Pasuto A, Titti G, Shafique M, Priyadarshana DGT (2018) An international program on Silk Road Disaster Risk Reduction-a Belt and Road initiative (2016-2020). J Mt Sci 15:1383-1396. https://doi.org/10.1007/ s11629-018-4842-4

Liu W, Dunford M (2016) Inclusive globalization: unpacking China's Belt and Road Initiative. Area Dev Policy 1:323-340. https://doi. org/10.1080/23792949.2016.1232598

Liu C, Li W, Wu H, Lu P, Sang K, Sun W, Chen W, Hong Y, Li R (2013) Susceptibility evaluation and mapping of China's landslides based on multi-source data. Nat Hazards 69:1477-1495. https://doi.org/10.1007/s11069-013-0759-y

Margottini C, Canuti P, Sassa K (eds) (2013) Landslide science and practice. Springer, Berlin. https://doi.org/10.1007/ 978-3-642-31325-7

Pasuto A, Tagliavini F (2007) Landslide susceptibility and hazard mapping in high mountain regions: application in the Italian Alps. Guidelines for mapping areas at risk of landslides in Europe. Institute for Environment and Sustainability Joint Research Centre, Rome, pp 27-30

Pedregosa F, Varoquaux G, Gramfort A, Michel V, Thirion B, Grisel O, Blondel M, Prettenhofer P, Weiss R, Dubourg V, Vanderplas J, Passos A, Cournapeau D, Brucher M, Perrot M, Duchesnay É (2011) Scikit-learn: machine learning in python. J Mach Learn Res 12:2825-2830

Pham BT, Pradhan B, Tien Bui D, Prakash I, Dholakia MB (2016) A comparative study of different machine learning methods for landslide susceptibility assessment: a case study of Uttarakhand area (India). Environ Model Softw 84:240-250. https://doi.org/ 10.1016/j.envsoft.2016.07.005

Reichenbach P, Rossi M, Malamud BD, Mihir M, Guzzetti F (2018) A review of statistically-based landslide susceptibility models. Earth Sci Rev 180:60-91. https://doi.org/10.1016/j.earscirev.2018. 03.001

Remondo J, González A, De Terán JRD, Cendrero A, Fabbri A, Chung C-JF (2003) Validation of landslide susceptibility maps; examples and applications from a case study in northern Spain. Nat Hazards 30:437-449. https://doi.org/10.1023/B:NHAZ.0000007201. 80743.fc

Reuter HI, Nelson A, Jarvis A (2007) An evaluation of void-filling interpolation methods for SRTM Data. Int J Geogr Inf Sci 21:9831008. https://doi.org/10.1080/13658810601169899

Saaty TL (1990) How to make a decision: the analytic hierarchy process. EJOR 48:9-26

Safanelli JL, Poppiel RR, Ruiz LFC, Bonfatti BR, de Mello FA, RizzoDemattê RJAM (2020) Terrain analysis in google earth engine: a method adapted for high-performance global-scale analysis. ISPRS Int J Geo Inf 9:400. https://doi.org/10.3390/ijgi9060400

Saponaro A, Pilz M, Bindi D, Parolai S (2015) The contribution of EMCA to landslide susceptibility mapping in Central Asia. Ann Geophys. https://doi.org/10.4401/ag-6668

Soeters R, Westen CJ van (1996) Slope instability recognition, analysis, and zonation. Landslides, investigation and mitigation (Transportation Research Board, National Research Council, Special Report ; 247), pp 129-177

Stanley T, Kirschbaum DB (2017) A heuristic approach to global landslide susceptibility mapping. Nat Hazards 87:145-164. https://doi. org/10.1007/s11069-017-2757-y

Titti G, Sarretta A (2020) CNR-IRPI-Padova/SZ: SZ plugin. Zenodo. https://doi.org/10.5281/zenodo.3843276

Van Westen CJ, Castellanos E, Kuriakose SL (2008) Spatial data for landslide susceptibility, hazard, and vulnerability assessment: an overview. Eng Geol 102:112-131. https://doi.org/10.1016/j. enggeo.2008.03.010

Wilde M, Günther A, Reichenbach P, Malet J-P, Hervás J (2018) PanEuropean landslide susceptibility mapping: ELSUS version 2. J Maps 14:97-104. https://doi.org/10.1080/17445647.2018.14325 11

Yao X, Tham LG, Dai FC (2008) Landslide susceptibility mapping based on support vector machine: a case study on natural slopes of Hong Kong, China. Geomorphology 101:572-582. https://doi. org/10.1016/j.geomorph.2008.02.01

Publisher's Note Springer Nature remains neutral with regard to jurisdictional claims in published maps and institutional affiliations. 